Document downloaded from:

http://hdl.handle.net/10251/119061

This paper must be cited as:

Cort, JL.; Estruch, VD. (2019). Review of Recent Studies on the Absolute and Relative Growth of Atlantic Bluefin Tuna: Similarities with the Pacific Bluefin Tuna. Reviews in Fisheries Science \& Aquaculture. 27(1):88-105. https://doi.org/10.1080/23308249.2018.1488817

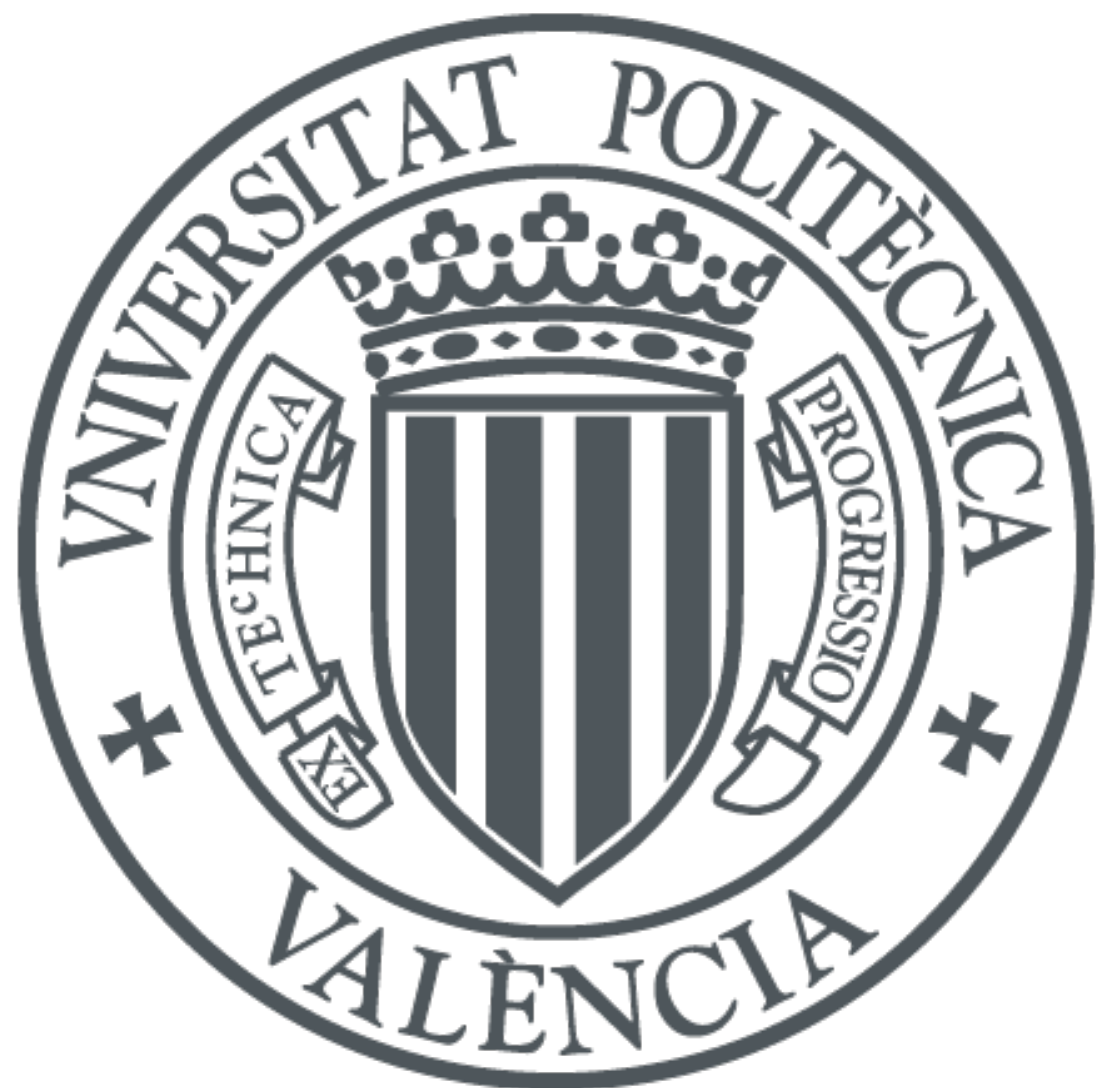

The final publication is available at

http://doi.org/10.1080/23308249.2018.1488817

Copyright Taylor \& Francis

Additional Information

This is an Accepted Manuscript of an article published by Taylor \& Francis in Reviews in Fisheries Science \& Aquaculture on2019, available online:

http://doi.org/10.1080/23308249.2018.1488817 


\title{
Review of recent studies on the absolute and relative growth of Atlantic bluefin tuna and similarities with Pacific bluefin tuna
}

\author{
José L. Cort ${ }^{1}$ and Vicente D. Estruch ${ }^{2}$ \\ ${ }^{1}$ Instituto Español de Oceanografía, Centro Oceanográfico de Santander (España) \\ ${ }^{2}$ Instituto de Investigación para la Gestión Integrada de Zonas Costeras (IGIC), Universitat Politècnica de Valencia (España)
}

\begin{abstract}
This study aims to clarify some aspects of the growth of Atlantic bluefin tuna, Thunnus thynnus (L.), (ABFT) mainly regarding parameters of the growth equation and of relative growth, in this case length-weight relationships. There is a great volume of literature on these matters and there is a danger that the resulting confusion may give rise to mistaken decisions.
\end{abstract}

In spite of the publication of 55 articles on absolute growth $(F L>50 \mathrm{~cm})$, which contain a total of 43 growth equations, no consensus has yet been reached within the ABFT assessment group (AG) of the SCRS on parameters such as $L_{\max }$ and $L_{\infty}$. The results of the present study indicate that the $L_{\infty}=314.9 \mathrm{~cm}$ of the growth equation used for the western stock by the AG from $2010\left(L t=314.9\left[1-e^{-0.089(t+1.13)}\right]\right)$, which was discarded in 2016, lies within the confidence limits of the maximum Ls presented in this study $\left(L_{\max }=321.4 \pm 8.7 \mathrm{~cm}\right)$, confirming that this equation fit the biology of the ABFT growth, and does so even better than that adopted in 2016 for the western stock, whose $L_{\infty}=271$ $\mathrm{cm}$ is statistically different from $L_{\max }$. There is a similar situation with regard to the length-weight relationships. 38 articles $(F L>50 \mathrm{~cm})$ have been consulted containing a total of 71 equations, but in spite of this the models adopted by the AG in 2014 underestimate the weight of spawners (> $2 \mathrm{~m}$ ) by up to $23 \%$.

The coincidence of the length-weight model for the ABFT western stock, discarded by the AG in 2014, with that of Pacific bluefin tuna, Thunnus orientalis (T \& S), (PBFT) indicates that both species must have the same growth, something that is not surprising since both were the same species until 2003. Other coincidences, such as the trend of condition factor $K$ in adults and the growth in the first months of life, could ratify it.

In the Pacific Ocean, where far fewer growth studies have been made on PBFT than on ABFT in the Atlantic and Mediterranean, the management of growth models for the purposes of stock assessment in the International Scientific Committee (ISC) makes more sense than that carried out by the SCRS on this matter.

\section{KEYWORDS}

Thunnus thynnus, Thunnus orientalis, growth parameters, $L_{\max }, L_{\infty}$, length-weight relationships 


\section{INTRODUCTION}

Atlantic bluefin tuna, Thunnus thynnus (L.), from the Atlantic and Mediterranean, hereinafter referred to as ABFT, has suffered severe overfishing in the last decades, for this reason it is subject to a very strict regime of fishing regulation through quotas for the conservation of its resources under the supervision of the International Commission for the Conservation of Atlantic Tunas (ICCAT). The Commission has an ABFT assessment group under the Standing Committee on Research and Statistics (SCRS) which carries out periodic assessments of resources to examine the impact of such conservation measures on the population.

The age and growth of ABFT, which began to be studied almost a century ago, are of great importance for the correct evaluation of the species' resources. In this sense, since the meeting of the ABFT assessment group in 2010 (ICCAT, 2010a) two very similar growth equations have been applied to the two stocks for the first time: to the western stock, $L_{t}=314.90\left[1-\mathrm{e}^{-0.089(t+1.13)}\right]$ (Restrepo et al., 2010), and to the eastern stock, $L_{t}=$ 318.85 [1- $\mathrm{e}^{-0.093(t+0.97)}$ (Cort, 1991; Cort et al., 2014). The latter has been applied in the SCRS ABFT group since 1991. This use of similar equations represented a great advance with respect to previous assessments of ABFT stocks, as up until then two very different equations had been used $\left(L_{t}=382\left[1-\mathrm{e}^{-0.707(t+0.079)}\right]\right)$ (Turner and Restrepo, 1994) for the western stock, and Cort (1991) for the eastern stock. However, a year later the group Luque et al. (2011) and Landa et al. (2011) put forward alternative relationships for the eastern ABFT stock arguing that, based on reported ABFT catch lengths, the estimated $L_{\infty}=382.7 \mathrm{~cm}$ and $L_{\infty}=348 \mathrm{~cm}$ were more realistic than the currently used $L_{\infty}$ for this stock $(318.85 \mathrm{~cm})$.

In view of all this and because the ICCAT Manual (ICCAT, 2010b) and Juan-Jordá et al. (2012) provided values of $L_{\max }=426.7 \mathrm{~cm}$ and $L_{\max }=372 \mathrm{~cm}$, respectively, Cort et al. (2013) carried out a study of $L_{\max }$ based on a sample of around 2.5 million ABFT taken from 224 scientific publications $(2,184,978$ records) and available biometric data (273,050 records). Outliers had to be filtered from the latter under very reasonable scientific criteria based on Fulton's condition factor, $K$ (Ricker, 1975). The results show that the maximum fork length $\left(L_{\max }\right)$ observed in eastern Atlantic and Mediterranean ABFT fisheries is $319.93 \pm 11.3 \mathrm{~cm}$ (CI 95\%). The study concluded that the mean asymptotical length parameters, $L_{\infty}=314.9 \mathrm{~cm}$ (from Restrepo et al., 2010) and $L_{\infty}=$ $318.85 \mathrm{~cm}$ (from Cort, 1991), lie within these confidence limits, confirming that these equations fit the biology of the growth of this species and that there is no scientific justification for changing them.

Despite this extensive work the group continued publishing articles on this subject. The results of the latter differ greatly among one another: Rodríguez-Marín et al. (2013): $L_{\infty}=380 \mathrm{~cm} ; L_{\infty}=392 \mathrm{~cm}$; Luque et al. (2014): $L_{\infty}=327 \mathrm{~cm}, L_{\infty}=382 \mathrm{~cm}$; Landa et al. (2015): $L_{\infty}=349 \mathrm{~cm}$; Rodríguez-Marín et al. (2016): $L_{\infty}=318 \mathrm{~cm}, L_{\infty}=324 \mathrm{~cm}$. The enormous variability of these results reveals great confusion and contradictions among these studies, especially considering the last paper presented to the SCRS by RodríguezMarín et al. (2017), which tends to accept $L_{\infty}=260-280 \mathrm{~cm}$ as the most likely for ABFT of the eastern stock. To add to the confusion even further, Murua et al. (2017) have published an article determining $L_{\max }=400 \mathrm{~cm}$. 
With regard to the growth equation of the western stock, Busawon et al. (2015) presented a new reading interpretation of otoliths, in which an overestimation of the stock by otolith readings by 3 years is attributed to Restrepo et al. (2010). Based on the latter, the ABFT stock assessment group has adopted the new model of Ailloud et al. (2017), whose $L_{\infty}=271 \mathrm{~cm}$.

Although Cort et al. (2015, 2016) and Cort and Estruch (2017) have published several articles on the subject, the present study discusses once more the length-weight models adopted by the SCRS in 2014

In light of the above, the specific objectives of the present study are:

i) Based on Cort et al. (2013), to estimate the value of $L_{\max }$ for the population as a whole (eastern and western stocks).

ii) To review the ABFT growth equation currently (pre-2017) used for the western stock (Restrepo et al., 2010) and to compare $L_{\max }$ and $L_{\infty}$ distributions of this equation with those recently adopted by the SCRS for that stock (Ailloud et al., 2017) under the normality hypotheses, with the aim of determining which better estimate ABFT growth.

iii) To determine the residuals when using the length-weight models adopted by the SCRS along with samples of which the actual weight is known, for which condition factor $K$ is applied.

iv) To analyze and discuss the weight underestimation of length-weight relationship models adopted by the SCRS in 2014, including recent biological information of Pacific bluefin tuna, Thunnus orientalis (T. \& S.), (PBFT).

v) To compare the management of growth models of ABFT and PBFT carried out in scientific committees of the Atlantic and Pacific oceans.

\section{MATERIAL AND METHODS}

\section{$L_{\max }$ analysis}

Cort et al. (2013) carried out an extensive review of scientific publications on ABFT from most known fisheries, and specifically those containing biological information referring to ABFT $L s$ in $\mathrm{cm}$ or $W$ in $\mathrm{kg}$, for the purpose of providing the maximum and minimum values of $L$ and $W$ of ABFT sampled. The study includes a great deal of unpublished biological information from diverse research institutions and ABFT fishing and commercial companies. The studies consulted run from old records of catches of large specimens taken in the North Sea between 1605 and 1921 (Le Gall, 1927) to recent electronic tagging studies (Block et al., 2009) and other biological samplings (Golet, 2010).

\section{$\boldsymbol{L}_{\infty}$ estimation}

Of the 55 studies on absolute growth made for ABFT (fork length $>50 \mathrm{~cm}$ ) in the Atlantic and Mediterranean, the 32 containing growth equations were analyzed by Cort et al. $(2015 ; 2017)$. In total, 43 equations were analyzed on the basis of $L_{\infty}$ and $L_{\max }$ and 
the confidence intervals shown in Cort et al. (2013). The present study only analyzes the models used in the ABFT stock assessment group. Namely:

The growth equation for the eastern Atlantic bluefin tuna stock (Cort, 1991; Cort et al., 2014) is a combined growth curve using modal progression data for ages 1 to 8 (53.5$177.2 \mathrm{~cm}$ ) from the Bay of Biscay (Cort, 1990) and direct age-length observations (fin spine sections) for ages 9-15 (190-247 cm) from the traps of southern Spain (Rey et al., 1987; Cort, 1990). Samples used correspond to the month of June, the month of birth for the ABFT in the western Mediterranean (García et al., 2003 and 2005); this makes the sampling season equivalent in both areas. By grouping the mean values at age from the Bay of Biscay with those of the traps, the von Bertalanffy growth model could be applied. Cort et al. (2014) used the same data and tag-recovery data from tagging surveys in the Bay of Biscay, western Mediterranean and western Atlantic $(n=131)$.

Restrepo et al. (2010) used combined otolith-based age readings with the size frequency distributions of small (ages 1-3) ABFT caught by purse seiners in the 1970s; the accuracy of the age readings has been validated with bomb radiocarbon dating (Neilson and Campana, 2008). These age readings are primarily for large ABFT (ages 5 and older) and indicate slower growth and older ages than was previously assumed (Turner and Restrepo, 1994). However, an analysis of these data resulted in growth curves that predicted very small mean sizes for the youngest age group, which could be a result of the lack of small fish in the data used. The von Bertalanffy (1938) growth model was applied.

Ailloud et al. (2017) growth parameters were derived from an integrated analysis of tagrecapture data and otolith age-length. Otolith samples were prepared and read by experts following the standardized protocol outlined in Secor et al. (2014) and Busawon et al. (2015), which prescribes the use of a reference scale to identify the first annulus and multiple reads per otolith to detect any inconsistencies and reduce ageing error. Strict data quality control measures were applied to the tagging data for quality assurance and a subsample of $n=1,118$ records were retained for use in the analysis. Two forms of the Schnute growth model were considered: the Richards model and the von Bertalanffy model.

\section{Determination of outliers and Fulton's condition factor (K)}

According to Cort et al. (2013):

Grubbs (1969) defined an outlier as: "An outlying observation, or outlier, is one that appears to deviate markedly from other members of the sample in which it occurs.

Outliers can occur by chance in any distribution, but they are often indicative either of measurement error or that the population has a heavy-tailed distribution. In the former case one wishes to discard them or use statistics that are robust to outliers, while in the latter case they indicate that the distribution has high kurtosis and that one should be very cautious in using tools or intuitions that assume a normal distribution".

In order to remove outliers of $L$ and $W$ from various datasets available, the Fulton's condition factor $K$ was calculated for each and every fish. 
Fulton's condition factor $(K)$ is defined as:

$K=10^{5} * W / L^{3}$

where, $W=$ round weight, in $\mathrm{kg} ; L=$ fork length, in $\mathrm{cm}$.

According to Deguara et al. (2013), Tukey's outlier method (Tukey, 1977; Hoaglin et al., 1983) was then used on the values of factor $K$ to detect and eliminate outliers.

After applying Tukey's methodology for outliers, the box-and-whisker plots were shown in Cort et al. (2013). The upper and lower limits of $K$ indicated from this analysis are between 1.47 and 2.56 .

With this methodology, common mistakes such as change of length by weight, and vice versa, or typography etc. can be eliminated from datasets. Some examples taken from Figure 1 of Cort et al. (2013) help us to understand this issue:

$L=382 \mathrm{~cm} ; W=560 \mathrm{~kg} ; K=1.0$

On the contrary:

$L=135 \mathrm{~cm} ; W=310 \mathrm{~kg} ; K=12.6$

The former might be called 'flat' tunas, and the latter, 'rounded' tunas.

The first set would include ABFT with $L_{\max }$ and $W_{\max }$ values of ICCAT Manual (ICCAT, 2010b):

$L=427 \mathrm{~cm} ; W=726 \mathrm{~kg} ; K=0.93$

The evolution of $K$ throughout the year is studied by means of the samples used in the present work. The results have been compared with $K$ values obtained using the monthly $L-W$ equations of Rodríguez-Marín et al. (2015) for a fixed value of straight fork length $(S F L)=220 \mathrm{~cm}$.

In order to verify the relationship between $K$ and the residual obtained by applying different length-weight equations, various analyses on samples whose size and actual weight are known have been conducted.

\section{Length-weight relationships adopted by the SCRS}

Cort et al. (2015), and Cort and Estruch (2016; 2017) conducted statistical analyses of the models recently adopted by the SCRS. In these articles two bi-variant samples ( $S F L$ $(\mathrm{cm}), R W(\mathrm{~kg}))$ were used with the aim of validated them and establishing which of the models analyzed best fitted the reality represented by the samples, and would therefore have the greatest descriptive and predictive power.

The sample for the western stock ( $n=698$ ABFT) is based on data of spawners from the Gulf of Mexico (Knapp et al., 2010) and from fisheries of Canada (Caddy et al., 1976; Butler et al., 1977; Smith et al., 2006; Corrigan et al., 2007; Fraser, 2008 and database 
from Fisheries and Oceans Canada). The sample contains a few young ABFT obtained from Rivas (1954), Baglin (1976); Farber and Chewning (1980); Hurley and Iles (1982), and our own data from transatlantic migrations (East to West), cited in Cort (1990).

The sample for the eastern stock $(n=474$ ABFT) is based on samples from the Atlantic traps of Morocco (Abid et al., 2015 and INRH Database), Portugal (IPMA database, in Cort et al., 2013) and Spain (Rodríguez-Roda, 1967 and IEO database), and a number of samples from ICCAT-GBYP database selected at random, covering the lack of young ABFT.

From all the statistical analysis carried out, the present study has recovered the residual analysis of the population models (for western and eastern stocks) adopted by SCRS.

For a linear or non-linear regression model, the difference between the observed value of the dependent variable $(y)$ and the predicted value $(\hat{y})$ is called the residual, $e: e=y-$ $\hat{y}$. For an appropriate model the mean of the residuals should be close to zero and the standard deviation should not be too large. If the residuals are represented by plotting its values on the vertical axis and the independent variable on the horizontal axis (residual plot), for an appropriate model the points in the residual plot must be randomly dispersed around the horizontal axis.

\section{Review of growth equations and length-weight relationships for ABFT and PBFT}

A review of growth papers (absolute and relative) is made, emphasizing those used in the stock assessment groups of SCRS and ISC (International Scientific Committee) of the Western \& Central Pacific Fisheries Commission (WCPFC). An analysis is made of how these two scientific committees manage the growth models used for stock assessment of ABFT and PBFT.

\section{Capture of a giant PBFT in the Pacific Ocean}

On the capture of the largest PBFT captured to date published by the Japanese press (information contrasted with Japanese scientists), a comparison of length-weight relationship of PBFT (Shimose et al., 2009) has been established with several lengthweight models of ABFT (Parrack and Phares, 1979; Rodríguez-Marín et al., 2015). The purpose of this comparison is to determine which best fits the data of the largest ABFT and PBFT captured. In this sense, the data of the largest specimens recorded in the Pacific and Atlantic oceans have also been superimposed on the length-weight models.

The Japanese length-weight relationship refers to gilled and gutted weight, and so the conversion factor of ABFT of 1.16 has been applied (ICCAT, 1997).

\section{Parallelism and differences of some biological parameters related to growth between ABFT and PBFT}

Until 2003 both species were considered a single species, and for this reason similarities in some parameters related to growth have been found. Based on diverse synopsis and recent articles, spawning season, $K$ factor, and growth of group 0 and other groups are analyzed in the present study. 


\section{RESULTS}

\section{$L_{\max }$ and $L_{\infty}$ analysis}

From a sample larger than 2.4 million ABFT (Table 1), the mean $L_{\max }$ was established at $321.4 \pm 8.7 \mathrm{~cm}(\mathrm{SD})$ for the Atlantic and Mediterranean (both stocks). The largest wild specimens of the eastern stock are the following: a $725 \mathrm{~kg}$ fish caught in the Marmara Sea in 1936 (Lebedeff, 1936), a record validated by the International Commission for the Exploration of the Mediterranean, CIEM (Heldt, 1938). Akyüz and Artüz (1957) sampled an ABFT of $330 \mathrm{~cm}$ caught in the Marmara Sea in 1956. Hamre et al. (1971) carried out further sampling in the market of Istanbul in 1967 and 1968 and measured ABFT of $320 \mathrm{~cm}$. For the western stock, Crane (1936) mentions a $726 \mathrm{~kg}$ specimen landed in Portland (Maine), but refers to a news article from the press. The official record of the largest ABFT captured in the western Atlantic is $679 \mathrm{~kg}$, a fish caught in Nova Scotia waters in 1979 (Fraser, 2008), the current Guinness world record. Fraser (pers. commun.) reported the fish size: Ten feet and six inches (sic): $320 \mathrm{~cm}$. Knapp et al. (2010) cite an ABFT of $326 \mathrm{~cm}(S F L)-655 \mathrm{~kg}-$, from the sampling carried out during the 2007 and 2008 spawning seasons in the Gulf of Mexico.

Di Natale et al. (2017) cite a 1,056 kg wild ABFT caught by a Spanish longliner in the Mediterranean in 2002 and auctioned at the Tokyo fish market the same year (Di Natale, pers. commun.). With respect to this, IEO has been monitoring all catches of Spanish longliners in the Mediterranean for more than four decades, especially swordfish (Xiphias gladius, L.) and ABFT (De la Serna et al., 2004), and this fish does not appear in any database. 
Table 1. Results of the largest ABFT observed by geographical area and source of information. Cort et al. (2013)

\begin{tabular}{|c|c|c|c|c|c|c|c|}
\hline Zone & $\begin{array}{l}\text { Total ABFT } \\
\text { Sample size }\end{array}$ & $\begin{array}{l}\text { Publications } \\
\text { consulted }\end{array}$ & $\begin{array}{r}\text { Unpublished Db } \\
\text { (ABFT sampled) }\end{array}$ & $\begin{array}{c}L_{\max }(\mathrm{cm}) \\
\text { observed } \\
\text { (wild) }\end{array}$ & Place/Source & $\begin{array}{c}W_{\max }(\mathrm{kg}) \\
\text { observed } \\
\quad \text { (wild) }\end{array}$ & Place/Source/Observations \\
\hline Eastern \& Central Med & 749,257 & 55 & 15,184 & 330 & $\begin{array}{c}\text { Marmara and Black } \\
\text { seas/Akyüz \& Artïz } \\
(1957)\end{array}$ & 725 & $\begin{array}{c}\text { Marmara sea/ Lebedeff (1936), } \\
\text { Heldt (1938) }\end{array}$ \\
\hline Western Med & 505,470 & 36 & 51,639 & 310 & \begin{tabular}{|c|} 
Tyrrhenian sea/Arena \\
$(1981,1982) ; \mathrm{Di}$ \\
Natale et al. (2003, \\
2005) \\
\end{tabular} & 685 & Sardinia trap/Sarà (1969) \\
\hline Central/Eastern Atlantic & 561,365 & 73 & 191,837 & 319.8 & \begin{tabular}{|} 
Canary islands/Santos \\
Guerra \\
$(1976 a, b ; 1980) ;$ \\
ICCAT (1976)
\end{tabular} & 560 & $\begin{array}{c}\text { Norwegian waters/Nøttestad, } \\
\text { based on Hamre's data }\end{array}$ \\
\hline Western Atlantic & 368,886 & 60 & 14,390 & 326 & $\begin{array}{c}\text { Gulf of Mexico/Knapp } \\
\text { et al. (2010) }\end{array}$ & 679 & $\begin{array}{l}\text { Canadian waters (Nova } \\
\text { Scotia)/Fraser } \\
\text { (2008)/Recreational fishing } \\
\text { world record }\end{array}$ \\
\hline TOTAL & $2,184,978$ & 224 & 273,050 & & & & \\
\hline
\end{tabular}

In Figures $1 \mathrm{~A}$ and $1 \mathrm{~B}$ the probability density functions (PDF) of $L_{\max }$ (mean $\pm \mathrm{SD}=321.4 \pm 8.7 \mathrm{~cm}$ ) are compared with those of $L_{\infty}$ by Ailloud et al. (2017) $($ mean $\pm \mathrm{SD}=271 \pm 22 \mathrm{~cm})$ and Restrepo et al. (2010) (mean $\pm \mathrm{SD}=314.9 \pm 19.4) \mathrm{cm}$, under the normality hypothesis.

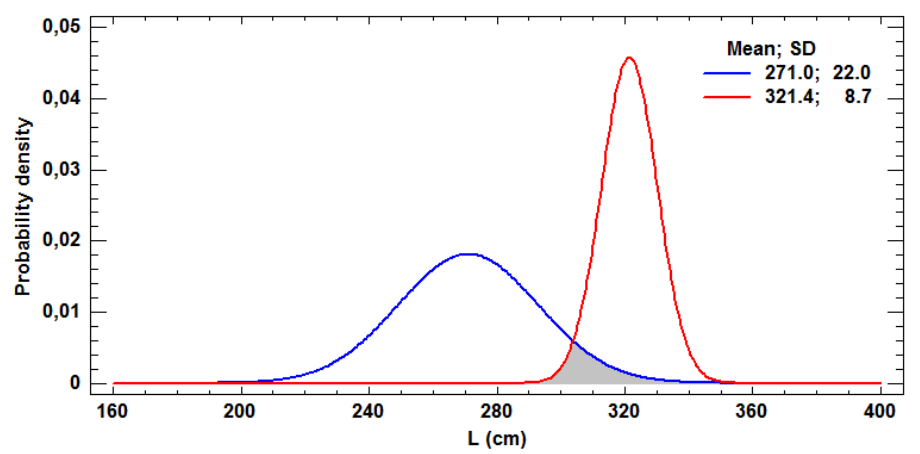

Figure 1A. Normal PDF plots. Blue line corresponds to the PDF of $L_{\infty}(271 \pm 22 \mathrm{~cm})$; red line corresponds to the PDF of $L_{\max }(321.4 \pm 8.7 \mathrm{~cm})$. The shaded area is the level of coincidence between both distributions

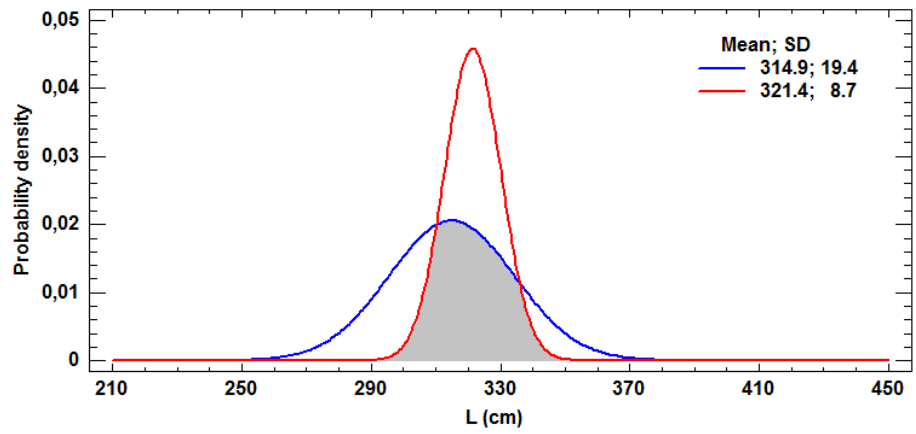

Figure 1B. Normal PDF plots. Blue line corresponds to the PDF of $L_{\infty}(314.9 \pm 19.4 \mathrm{~cm})$; red line corresponds to the PDF of $L_{\max }(321.4 \pm 8.7 \mathrm{~cm})$. The shaded area is the level of coincidence between both distributions 
In the first case there are two completely different distributions, with an approximate level of coincidence of only approximately 9\%, indicating that the adopted model (Ailloud et al., 2017) is statistically very far from the reality. In the second case the distributions are much more similar. For both, the mean values are similar and the standard deviations do not differ excessively, and the level of coincidence is approximately $60.3 \%$.

After analyzing 43 ABFT growth equations, Cort et al. (2014; 2017 found nine studies (from eastern and western stocks) in which the values of $L_{\infty}$ lie within the limits of $L_{\max }$ : Bard et al. (1978); Hattour (1984); Cort (1991; Cort et al., 2014); Negli and Naour (2014); Parrack and Phares (1979); Farber and Lee (1981); Restrepo et al. (2010); Luque et al. (2014), and Rodríguez-Marín et al. (2016).

\section{Estimation of $K$}

Different $K s$ applied to $L_{\infty}$ of Ailloud et al. (2017) and Restrepo et al. (2010) for the highest weights observed on ABFT are presented in Table 2.

Table 2. $K$ values for the highest weights, corresponding to $L_{\infty}$ and to the extremes of its confidence intervals, from Restrepo et al. (2010) and Ailloud et al. (2017)

\begin{tabular}{|c|c|c|c|c|c|c|c|c|c|c|c|c|}
\hline & & & & \multicolumn{2}{|c|}{$W=600$} & & \multicolumn{2}{|c|}{$W=650$} & & \multicolumn{2}{|c|}{$W=725$} & \multirow[b]{2}{*}{$K \mathrm{~s}$} \\
\hline & $L \_\mathrm{i}$ & $L \_$inf & $L \_\mathrm{s}$ & $K \mathrm{i}$ & $K$ & $K \mathrm{~s}$ & $K \mathrm{i}$ & $K$ & $K \mathrm{~s}$ & $K \mathrm{i}$ & $K$ & \\
\hline Ailloud et al. & 227.9 & 271.0 & 314.12 & 5.1 & 3.0 & 1.9 & 5.5 & 3.3 & 2.1 & 6.1 & 3.6 & 2.3 \\
\hline Restrepo et al. & 276.9 & 314.9 & 352.9 & 2.8 & 1.9 & 1.4 & 3.1 & 2.1 & 1.5 & 3.4 & 2.3 & 1.6 \\
\hline
\end{tabular}

$L \mathrm{i}=\operatorname{Linf}-1.96 * \mathrm{SD}$

$L s=\operatorname{Linf}+1.96 * \mathrm{SD}$

These results show that for Ailloud et al. (2017), the $K$-values corresponding to $L_{\infty}$ and $L_{i}$ remain outside the interval (1.47-2.56) and for Restrepo et al. (2010) only the values corresponding to $L_{i}$ remain outside, confirming the results of the previous exercise in which the latter is better adapted to the growth of ABFT than that adopted by the SCRS.

A compendium of works in which the actual value of the samples are estimated can be consulted in tables 10A and 10B of Cort and Estruch (2017). The evolution of $K$ throughout the year obtained from these tables, and Figure 2 (summarized in Table 3) can be explained as follows: there are three periods, July-August (after reproduction), when ABFT is skinny. Immediately afterwards there is a growth period of high fattening extending from September until December. And finally, at the end of the boreal winter, when reproduction begins (March-April), the $K$ index drops back to the levels of June, which is the lowest point, when ABFT is in full reproduction. 


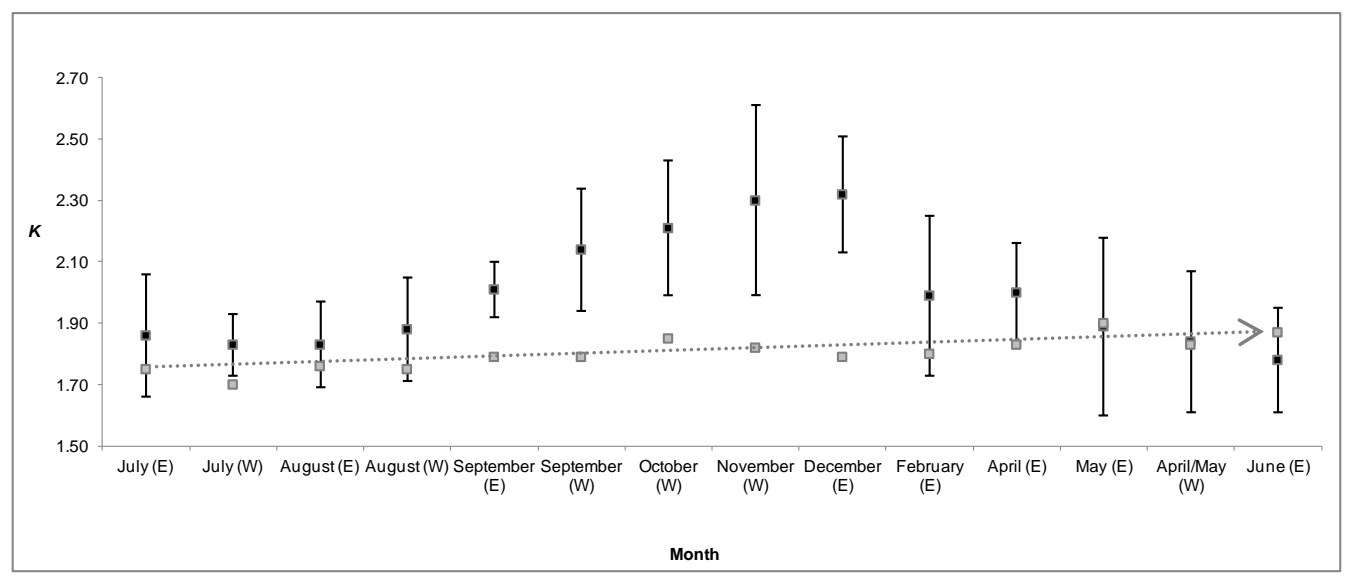

Figure 2. Evolution of $K$ throughout the year

Mean values obtained by using data of tables 10A and 10B of Cort and Estruch (2017)

Values obtained by using monthly $L-W$ of adopted equations (Rodríguez-Marín et al., 2015).

See data, Table 3.

$\rightarrow K$ trend using monthly $L-W$ equations adopted by SCRS (Rodríguez-Marín et al., 2015)

In the same figure the values of $K$ are presented using monthly length-weight equations adopted by SCRS (Rodríguez-Marín et al., 2015). In this case, $K$ values are very low, not reaching $K=2$ at any time. The line is flat and does not manifest the high fattening period (September-December). Values only coincide in May. In June, however, $K$ is overestimated.

Table 3. Evolution of $K$ throughout the year (E: East Atlantic samples. W: West Atlantic samples). Sample size $=1,315$ ABFT

- Mean values obtained by using data from Tables 10A and 10B of Cort and Estruch (2017).

Values obtained by using monthly $L-W$ adopted equations (Rodríguez-Marín et al., 2015).

(LL, Long line)

\begin{tabular}{|c|c|c|c|c|c|c|c|c|}
\hline \multicolumn{9}{|c|}{ Western and Eastern Atlantic } \\
\hline & $K$ & Max & Min & Stand Dev. & $N$ & Observations & $K$-ICCAT & $\begin{array}{l}W(\mathrm{~kg}), \\
220 \mathrm{~cm}\end{array}$ \\
\hline July (E) & 1.86 & 2.06 & 1.66 & 0.20 & 127 & $\begin{array}{c}\text { Traps, Hand line (S. of } \\
\text { Gibraltar) }\end{array}$ & 1.75 & 187 \\
\hline July (W) & 1.83 & 1.93 & 1.73 & 0.10 & 57 & Canada & 1.70 & 181 \\
\hline August (E) & 1.83 & 1.97 & 1.69 & 0.14 & 144 & Traps (S. of Gibraltar) & 1.76 & 187 \\
\hline August (W) & 1.88 & 2.05 & 1.71 & 0.17 & 135 & Canada & 1.75 & 187 \\
\hline September (E) & 2.01 & 2.10 & 1.92 & 0.09 & 16 & North Sea (Spor) & 1.79 & 191 \\
\hline September (W) & 2.14 & 2.34 & 1.94 & 0.20 & 153 & Canada & 1.79 & 190 \\
\hline October $(\mathrm{W})$ & 2.21 & 2.43 & 1.99 & 0.22 & 122 & Canada & 1.85 & 197 \\
\hline November $(\mathrm{W})$ & 2.30 & 2.61 & 1.99 & 0.31 & 29 & Canada & 1.82 & 194 \\
\hline December $(\mathrm{E})$ & 2.32 & 2.51 & 2.13 & 0.19 & 51 & Morocco (Hand line) & 1.79 & 191 \\
\hline February (E) & 1.99 & 2.25 & 1.73 & 0.26 & 39 & Traps (S. of Gibraltar) & 1.80 & 191 \\
\hline April (E) & 2.00 & 2.16 & 1.84 & 0.16 & 91 & Traps (S. of Gibraltar) & 1.83 & 195 \\
\hline May (E) & 1.89 & 2.18 & 1.60 & 0.29 & 211 & Traps (S. of Gibraltar) & 1.90 & 201 \\
\hline April/May (W) & 1.84 & 2.07 & 1.61 & 0.23 & 25 & Gulf of Mexico (LL) & 1.83 & 196 \\
\hline June (E) & 1.78 & 1.95 & 1.61 & 0.17 & 115 & Traps (S.of Gibraltar) & 1.87 & 199 \\
\hline
\end{tabular}

The above issue can be corroborated as follows: Figure 3 shows the relationship between the value of $K$ for each sample from Tables10A and 10B of Cort and Estruch (2017), and the residuals obtained for each applying the monthly length-weight equations adopted by SCRS (Rodríguez-Marín et al., 2015). 
The results clearly show how the residuals increase as $K$ also increases. The residual from $K$ can be predicted by the regression line. When fish are in the low fattening condition the residual value is low $(<5 \%)$, while for fish in the high fattening condition the residuals can reach $23 \%$.

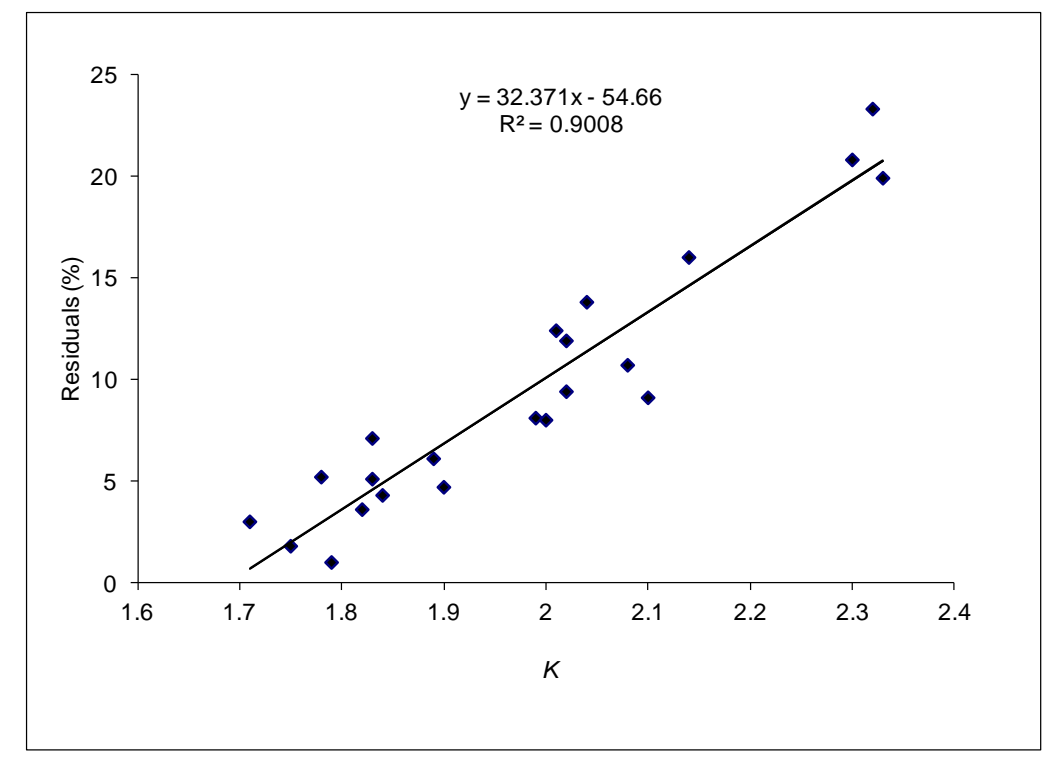

Figure 3. Relationship between $K$ and residuals obtained by applying monthly length-weight models adopted by SCRS

\section{Length-weight relationships adopted by the SCRS}

Based on a statistical analysis, Cort et al. (2015) and Cort and Estruch (2016; 2017) demonstrated that the length-weight relationships adopted by SCRS in 2014 (ICCAT, 2014a,b), referred to as West and East in the present study, underestimate the weight of spawning ABFT (> $2 \mathrm{~m}$ ) by up to $14 \%$.

From the results of the analysis of the residuals (Table 4) it is observed that the mean and median values point to an important asymmetry of the residuals for the models West and East, which can be confirmed visually in Figures 4A, 4B. The positive values of the mean (as well as the confidence intervals) for West and East confirm the tendency of these models to underestimate weight. Besides, the requisite that the $95 \%$ confidence interval for the mean of the residuals contains the value 0 is not fulfilled.

Table 4. Summary statistics for the residuals corresponding to the different models analyzed and confidence intervals (95\%) for the mean

\begin{tabular}{|c|c|c|}
\hline & West & East \\
\hline Count & 698 & 474 \\
\hline Mean & 35.4744 & 11.7863 \\
\hline Standard deviation & 37.1325 & 19.7551 \\
\hline Median & 28.619 & 0.4584 \\
\hline $\begin{array}{c}\text { 95\% confidence } \\
\text { interval for the mean }\end{array}$ & $\begin{array}{l}35.4744+/-2.7547 \\
{[32.7197 ; 38.2291]}\end{array}$ & $\begin{array}{l}11.7863+/-1.783 \\
{[10.0033 ; 13.5693]}\end{array}$ \\
\hline
\end{tabular}




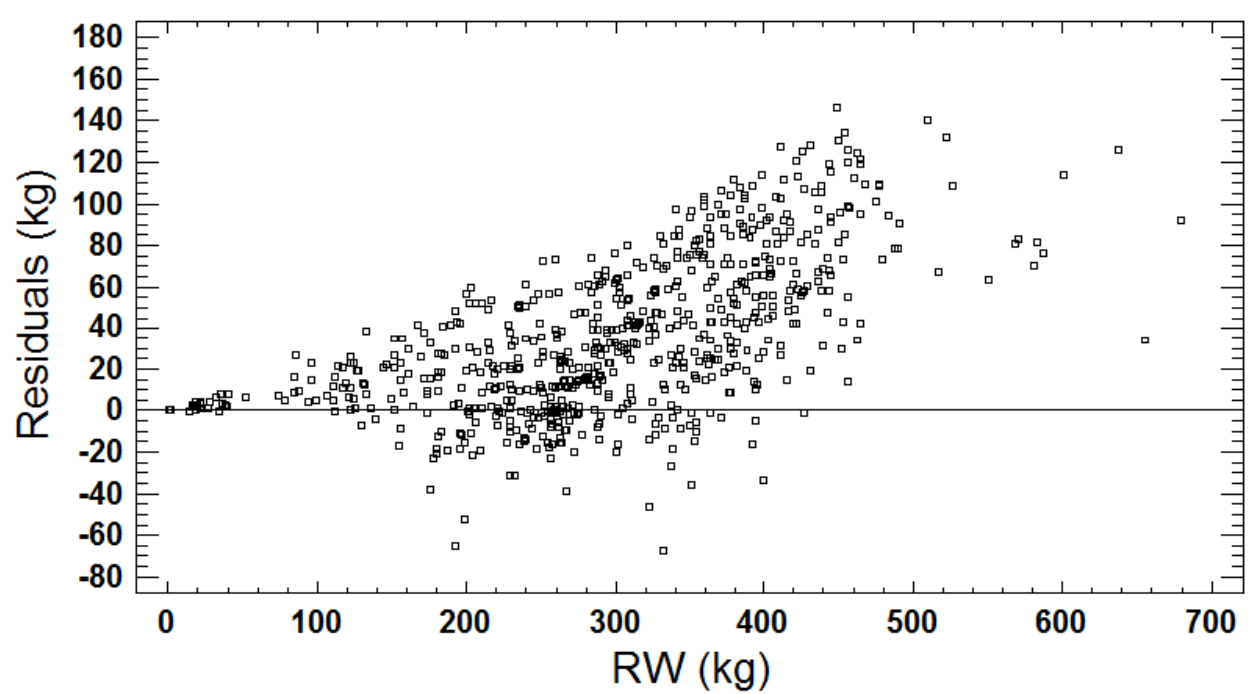

Figure 4A. Residual plot. The figure corresponds to the model linked to the equation adopted for the western stock (West)

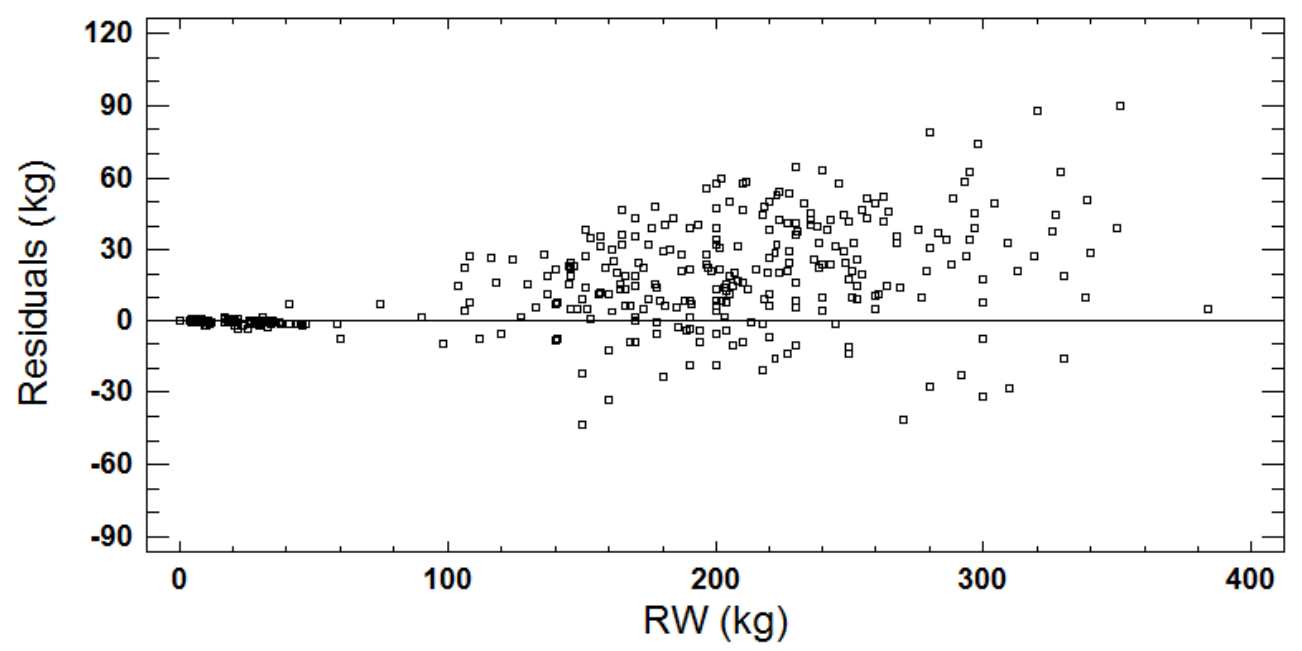

Figure 4B. Residual plot. The figure corresponds to the model linked to the equation adopted for the eastern stock (East)

In view of all this, it can be concluded that adopted models West and East are not suitable for explaining the behaviour of the sample data.

\section{Review of growth equations and length-weight relationships for ABFT and PBFT}

In the latest reviews, Rooker et al. (2007), Cort et al. $(2013 ; 2014)$ and Murua et al. (2017), 55 articles $(F L>50 \mathrm{~cm})$ on the absolute growth of wild ABFT are reported. Of these, 32 contain 43 growth equations. In relation to length-weight relationships, Cort et al. (2013) report 37 articles with 57 equations. Rodríguez-Marín et al. (2015) publish 12 monthly and 2 population equations (western and eastern stocks). 
The situation for PBFT is completely different since a total of 12 articles have been found: Aikawa and Kato (1938); Yukinawa and Yabuta (1967); Bayliff et al. (1991; 1993); Foreman (1996); Tanaka et al. (2007); Shimose et al. (2009); and Shiao et al. (2017), refer to absolute growth. Two deal with daily increments in otoliths at age 0: Itoh (2009), and Yamasaki et al. (2010). Shimose and Ishihara (2015) is a manual; and Tanabe and Kai (2007); and Shimose et al. (2009), deal with length-weight relationships.

\section{ABFT}

\section{Growth equations}

Parameters of Richards model for growth in Ailloud (2017) used for western stock (stock assessment, 2017):

$L_{t}=\left(33^{-0.12}+\left(270.6^{-0.12}-33^{-0.12}\right) \cdot \frac{1-e^{-0.22 \cdot t}}{1-e^{-7.48}}\right)^{-\frac{1}{0.12}}$

$L_{\infty}=271 \mathrm{~cm}$

This model replaces the previous one used for 2010 and 2014 stock assessements (Restrepo et al., 2010):

$L_{i}=314.90\left(1-\mathrm{e}^{-0.089(t+1.13)}\right)$

Current equation for ABFT (eastern stock) from Cort (1991); Cort et al. (2014):

$L_{t}=318.85\left(1-\mathrm{e}^{-0.093(t+0.97)}\right)$

\section{Length-weight relationships}

The models traditionally used for stock assessment, both eliminated in 2014, were:

Parrack and Phares (1979), western stock:

$R W=0.0000152 S F L^{3.0531}$

Arena (unpublished), in ICCAT (2006), eastern stock:

$R W=0.000019607 S F L^{3.0092}$

Models adopted in 2014, Rodríguez-Marín et al. (2015):

Western stock: $R W=0.0000159137 S F L^{3.020584}$

Eastern stock: $R W=0.0000315551 S F L^{2.898454}$ 


\section{PBFT}

\section{Growth equations}

Current equation for PBFT (Shimose et al., 2009):

$L_{t}=249.6\left(1-\mathrm{e}^{-0.173(t+0.254)}\right)$, slightly modified for 2016 stock assessement by Anonymous (2016):

$L_{l}=249.9\left(1-\mathrm{e}^{-0.188(t+0.422)}\right)$

\section{Length-weight relationships}

The relationship between fork length $(S F L, \mathrm{~cm})$ and gilled and gutted body weight $(B W$, $\mathrm{kg}$ ), published by Shimose et al. (2009) is:

$B W=3.3210^{-5} S F L^{2.89}$; slightly modified for 2014 stock assessment (Anonymous, 2014) by Kai (2007):

$R W=0.000017117 S F L^{3.0382}$

In both cases (growth curves and length-weight relationships) the new models adopted for the stock assessment in the Pacific are practically the same as the previous ones, while the opposite is true in the Atlantic.

\section{Capture of a giant PBFT in the Pacific Ocean}

On 06th March, 2017 the following news was published:

(http://www.tokyoreporter.com/2017/03/06/monster-tuna-caught-off-wakayama/)

"Weighing 446 kilograms and measuring 2.82 meters in length, the "king" kuro maguro, or northern bluefin tuna was pulled aboard a longline fishing vessel about 320 kilometers off the coast on Friday. The tuna is the largest by weight since statistics started being kept by a fishery cooperative in 1949. The previous record was a 417kilogram tuna landed in January of last year."

The captured giant had a $L=282 \mathrm{~cm}$ and $W=446 \mathrm{~kg}$ which, according to Japanese scientists consulted, would be gilled-and-gutted weight, so the actual weight was $517 \mathrm{~kg}$ (converted to round weight).

Table 5 and Figure 5 show two length-weight relationships for ABFT and PBFT (converted to round weight). Parrack and Phares (1979) model was discarded by the ABFT evaluation group in 2014 and Rodríguez-Marín et al. (2015) was the adopted model. 
Table 5. Length-weight models by different authors (Associated to Figure 5)

\begin{tabular}{|c|c|c|c|}
\hline & $\begin{array}{c}\text { Shimose } \\
\text { et al. } \\
(2009)\end{array}$ & $\begin{array}{c}\text { Parrack } \\
\& \text { Phares } \\
(1979)\end{array}$ & $\begin{array}{c}\text { R.-Marín } \\
\text { et al. } \\
(2015)\end{array}$ \\
\hline $\mathrm{a}$ & 3.3E-05 & $1.5 \mathrm{E}-05$ & $1.77 \mathrm{E}-05$ \\
\hline $\mathrm{b}$ & 2.89 & 3.0531 & 3.0013 \\
\hline$F L(\mathrm{~cm})$ & $\begin{array}{c}\text { Pacific } \\
(\mathrm{kg})\end{array}$ & $\begin{array}{c}\text { West } \\
\text { Atlantic } \\
(\mathrm{kg})\end{array}$ & $\begin{array}{c}\text { West } \\
\text { Atlantic } \\
(\mathrm{kg})\end{array}$ \\
\hline 50 & 3 & 2 & 2 \\
\hline 70 & 8 & 7 & 6 \\
\hline 90 & 17 & 14 & 13 \\
\hline 110 & 31 & 26 & 24 \\
\hline 130 & 50 & 43 & 39 \\
\hline 150 & 75 & 67 & 60 \\
\hline 170 & 108 & 98 & 88 \\
\hline 190 & 148 & 138 & 122 \\
\hline 210 & 198 & 187 & 165 \\
\hline 230 & 258 & 247 & 217 \\
\hline 250 & 328 & 318 & 279 \\
\hline 270 & 409 & 403 & 351 \\
\hline 290 & 503 & 501 & 435 \\
\hline 300 & 555 & 556 & 481 \\
\hline 305 & 582 & 584 & 506 \\
\hline 310 & & 614 & 531 \\
\hline 320 & & 677 & 584 \\
\hline
\end{tabular}

Data from the three largest recorded specimens have been superimposed on Figure 5:

- $\quad$ The giant PBFT caught off Wakayama on 03/03/2017: $F L=282 ; R W=517 \mathrm{~kg}$.

- The PBFT exhibited at Seikai National Fisheries Research Institute, Nagasakishi (Japan): $F L=302 ; R W=572 \mathrm{~kg}$ (Figure 6) $^{(1)}$.

- The ABFT, Guinness World Record: $F L=320 ; R W=679 \mathrm{~kg}$ (Fraser, 2008).

(1) A fish of wild origin kept in captivity for several years. 


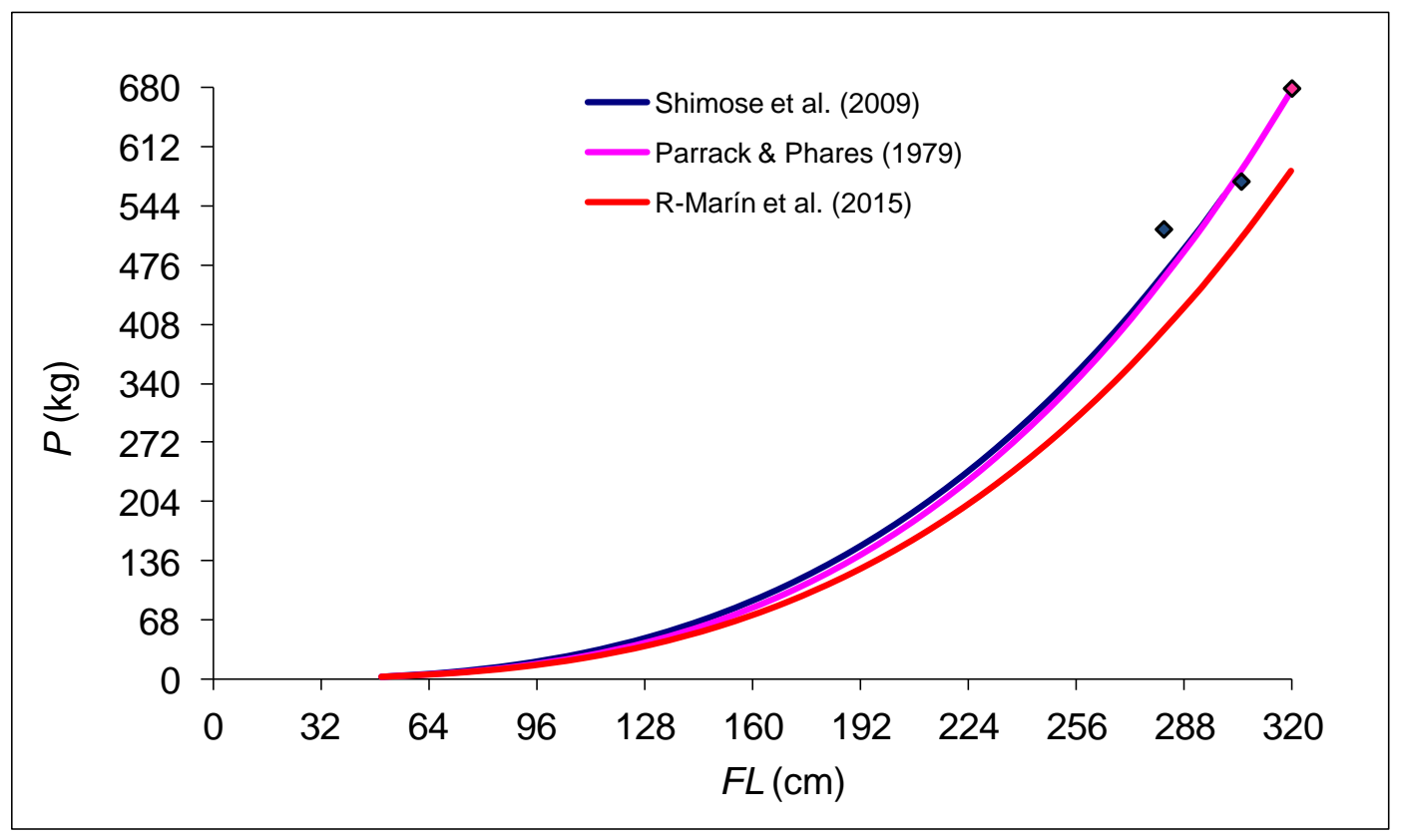

Figure 5. Length-weight models by different authors, associated to Table 6. Explanation of three points, in text.

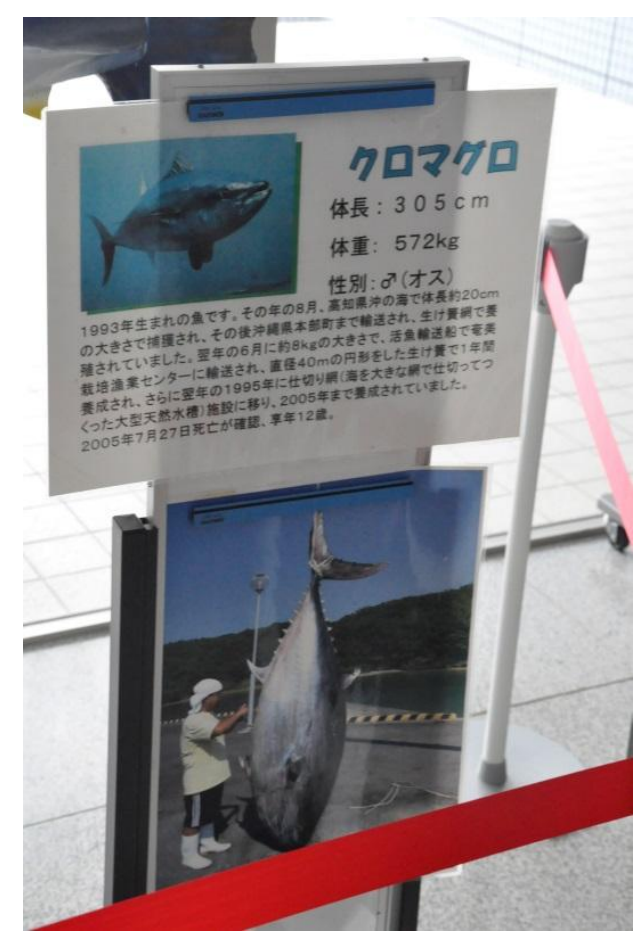

Figure 6. Photograph of a PBFT model (size 1:1) exhibited at Seikai National Fisheries Research Institute, Nagasaki-shi (Japan)

Surprisingly, the length-weight relationship of PBFT follows the same trend line of the ABFT length-weight relationship of western stock of Parrack \& Phares (1979), a model that perfectly fits the growth model of Restrepo et al. (2010). The coincidence is so pronounced that they are scarcely distinguishable in Figure 5. In contrast, the equation currently in use in the SCRS differs greatly from the other two. Parrack and Phares 
(1979) and Shimose et al. (2009) produce values of length and weight which are in accordance with the extreme but real superimposed specimens.

\section{Parallelism and differences of some biological parameters related to growth between ABFT and PBFT}

In West Atlantic there are two spawning areas, one located in the Gulf of Mexico (Mather et al., 1995; Rooker et al., 2007; ICCAT, 2010b) and another in the Slope Sea (Northwest Atlantic), according to Richardson et al. (2016). The reproduction period extends from May to early June (Gulf of Mexico) and between June and August (Slope Sea). In western and central Mediterranean Sea the reproduction period extends from June to early July (Tiews, 1963; Corriero et al., 2005; García et al., 2005) and from May to early June (in the Levantine Sea), according to Karakulak et al. (2004).

In the synopses of Yamanaka et al. (1963) and Bayliff (1994) it's mentioned that spawning of PBFT occurs between Japan and the Philippines in April, May, and June and off southern Honshu in July. Even in August larvae have been found in the Sea of Japan (Okiyama, 1974, 1979). According to Chen et al. (2006) spawning activity is believed to occur only in the western North Pacific Ocean especially from waters around the Ryukyu Islands to the Sea of Japan from June to August.

In general, it can be considered that ABFT and PBFT have very similar reproduction periods and sizes of the fish according to the spawning area or in captivity. The result can be verified in the following:

- As shown in Richardson et al. (2016), ABFT that reproduce in the Gulf of Mexico $\left(20-25^{\circ} \mathrm{N}\right)$ are larger/older than those of the Slope Sea $\left(40-45^{\circ} \mathrm{N}\right)$. In the first case, the modal value is between 15 and 17 years old; in the second, between 8 and 10 . Something similar happens in the Pacific, where the PBFT spawning in the southern area $\left(20-25^{\circ} \mathrm{N}\right)$ are larger/older $(190-260 \mathrm{~cm}$; from Chen et al., 2006; Shiao et al., 2017) than those spawning in the Sea of Japan, $\left(40-45^{\circ} \mathrm{N}\right), 100-223 \mathrm{~cm}$. The latter have been obtained from the sampling done by Shimose et al. (2009) in the fishing ports from the Sea of Japan during the spawning season.

- Both species reproduce at three years old in wild (Nakamura, 1943; cited by Hirota et al. 1976; Rodríguez-Roda, 1969) or aquaculture (Sawada et al., 2007; Berkovich et al. 2013).

-The trend of $K$ factor in adults between April and July is the same for the two species, as shown by Chen et al. (2006) and the present study.

-There is a very large coincidence in the growth of group 0. Sawada et al. (2007) give $27.0 \pm 1.9 \mathrm{~cm}$ total length $(T L), 248.7 \pm 80.6 \mathrm{~g}$ body weight $(B W)$ for specimens caught for aquaculture off the coast of Kii Peninsula, Central Honshu, Japan, from August 13-20, 1997. Converting $T L$ into $F L$, according to Cort (2009), the average size of the fish would be $23 \mathrm{~cm}(F L)$. La Mesa et al. (2005) caught juvenile (class 0) ABFT off the northern coast of Sicily between late August-November 2002 giving a $F L=22 \pm 3 \mathrm{~cm}$ for month II (August). The weight of these fish would range from $102 \mathrm{~g}$ to $258 \mathrm{~g}$, according to the size-weight relationship presented by these authors. 
The previous coincidences do not occur with the growth models used for ABFT (Ailloud et al., 2017; Cort et al., 2014) and PBFT (Shimose et al., 2009; Anonymous, 2016). The three models show differences for ages up to 10 years and from that age the trend towards $L_{\infty}$ also differs. Differences possibly due to the different methodologies used, as well as to the sampling variability.

\section{DISCUSSION}

Since the beginning of the 20th century 55 studies $(F L>50 \mathrm{~cm})$ of absolute growth of ABFT have been carried out using various methodologies, such as the reading of rings in scales, vertebrae, spines and otoliths, modal progression, tag-recaptures, backcalculated $L$, age length key, various mixed methods and others not specified. From these, 43 growth equations have been estimated in which the age of the fish is related, generally in years, together with length (Cort et al., 2014).

The ABFT $L_{\max }$ controversy dates back to the 1950s when Bigelow and Schroeder (1953), revision 1.1 (2002), referring to the ABFT, state: "This is the largest Gulf of Maine fish, except for some sharks; a length of 14 feet or more, and a weight of 1,600 pounds being rumored, with fish of 1,000 pounds not rare" $(14 \mathrm{ft}=426.7 \mathrm{~cm}, 1,600 \mathrm{lbs}=$ $726 \mathrm{~kg}$ ). Meanwhile, according to the ICCAT Manual (Chapter 2.1.5), ICCAT (2010b): "Its maximum length can exceed $4 \mathrm{~m}$ long. Its official maximum weight is $726 \mathrm{~kg}$, but weights up to $900 \mathrm{~kg}$ have been reported in various fisheries of the West Atlantic and Mediterranean Sea (Mather et al. 1995)". Cort et al. (2013) have shown that $4 \mathrm{~m} L_{\max }$ is not possible: "If it is indeed just a rumor, then some comments can be made in this respect. An $L$ of $426.7 \mathrm{~cm}$ is technically impossible. For an ABFT to reach such a size it would have to weigh $1,480 \mathrm{~kg}$ according to the general $L-W$ relationship of the western Atlantic of Parrack and Phares (1979). Moreover, the value of $K=0.94$ is far from the minimum size established for this species (Deguara et al., 2012) ${ }^{1}$. To date there is no scientific evidence whatsoever of the existence of ABFT of anything like this $W$; however, the $W$ of a 726-kg bluefin tuna would vary between $312 \mathrm{~cm}$ and $327 \mathrm{~cm}$ when applying the $L-W$ relationships of September-November of these authors, a value which makes more biological sense and fits in with $L_{\max }$ as determined in this study."

${ }^{1}$ This reference has become Deguara et al. (2013)

Murua et al. (2017) state: "Atlantic bluefin tuna attain the largest body size of any tuna species, reaching a length of more than four meters (Bigelow and Schroeder 1953) and a bodymass of nearly $700 \mathrm{~kg}$ (Fromentin and Powers 2005)". In other words, these authors give more credence to a rumour from 64 years ago than to a published scientific article in which it is demonstrated that $4 \mathrm{~m}$ is impossible, according to Cort et al. (2013). In addition, these authors ignore the official reference on weight made by Lebedeff (1936) and Heldt (1938). The fact that reference is still made to a maximum length of $4 \mathrm{~m}$ confuses the public and makes the results and conclusions of the study on this subject incorrect.

Cort et al. (2013) suggested that the following phrase from the ICCAT Manual refers to the maximum weight: "Its official maximum weight is $726 \mathrm{~kg}$, but weights up to $900 \mathrm{~kg}$ have been reported in various fisheries of the West Atlantic and Mediterranean Sea 
(Mather et al. 1995)", be changed to: "Its official maximum weight is $725 \mathrm{~kg}$ (Lebedeff, 1936; Heldt, 1938)".

In relation to the capture of a wild ABFT of $1,056 \mathrm{~kg}$ by a Spanish longliner in the Mediterranean Sea in 2002 cited by Di Natale et al. (2017), doubts remain since it does not appear in any official Spanish registers (IEO's and ports specialized in ABFT fishing with LL), nor in the press. Moreover, if a fact of such transcendence had taken place, it would have been published at that time by the press all over the world. In the same article, however, several ABFT of $780 \mathrm{~kg}$ from fattening farms are cited. According to Gordoa (2010), ABFT $>260 \mathrm{~kg}$ undergoes fattening of around $22 \%$ of its weight over a period of 3-5 months, and so these specimens would have entered the farm with about $640 \mathrm{~kg}$.

In the review of the bibliography and available biometric data outliers had to be filtered out since the ABFT databases have numerous errors that can be attributed to typographical errors or to confusing weights and sizes, among others. The outliers are of great importance in obtaining a model by least square methods because their inclusion or not in the sample can greatly influence the fitting parameters.

Although the outliers recognized may be possible, the relationship between the variables defined by the fitted model can be greatly affected by the outliers, which may introduce important bias in the model that would disappear if the data that should be treated as exceptions were eliminated from the data set.

In conclusion, if our goal is to fit a model that represents the usual behaviour of the relationship between length and weight, singular data may introduce undesirable bias in the final model predictions. If we do not consider the possible but unusual data for constructing the model, the model will represent the usual behaviour and the initial outliers will continue to be outliers in reference to the values predicted by the model.

The growth equations available in the literature for this species were analyzed to determine which provided the best representation of the known biology of ABFT. Eleven growth equations of 43 have a value of $L_{\infty}$ within the limits of $L_{\max }$ (Cort et al., 2014). This updated review demonstrates the availability of a large body of literature on age estimation and absolute growth of ABFT. With the analysis carried out, it is clearly possible to identify and conclude which are the equations that best fit the growth biology of this species, thereby ensuring the most accurate stock assessments can be carried out.

Assuming that $L_{\max }$ and $L_{\infty}$ must have similar values (do not forget that since $1957 L_{\max }$ remains at $330 \mathrm{~cm}$ ), the results of the present study indicate that the $L_{\infty}=314.9 \mathrm{~cm}$ of the growth equation used from 2010 by the SCRS ABFT assessment group for the western stock $\left(L t=314.9\left[1-e^{-0.089(t+1.13)}\right]\right)$ discarded in 2016, lies within the confidence limits of the maximum $L$ s presented in the study: $L_{\max }=321.4 \pm 8.7 \mathrm{~cm}$. These conclusions are also valid for the equation for the eastern stock $\left(L t=318.85\left[1-e^{-0.093(t+0.97)}\right]\right)$. The results confirm that these two equations fit the biology of the growth of the ABFT, even better than that adopted for the western stock (Ailloud et al., 2017), which has an $L_{\infty}=$ $271 \mathrm{~cm}$, statistically different from $L_{\max }$. The adopted model is based on a new interpretation of age from otoliths (Busawon et al., 2015) that strangely flattens in older ages and which questions the interpretation made by previous scientists (Restrepo et al., 2010). While von Bertalanffy's (1938) model does not fit the latter records on age, 
Richards' (1959) model does. Whatever the case, this new approach, which is supported by Rodríguez-Marín et al. (2017), acknowledges the filtering done by Cort et al. (2013) to be correct, but it is in complete contradiction with the $L_{\max }=400 \mathrm{~cm}$ of Murua et al. (2017).

Fulton's condition factor applied to the ABFT has been used by scientists throughout history and has provided optimal results. Rodríguez-Roda (1964) determined this index to compare the different states of fattening of ABFT during its migrations towards the spawning areas in the Mediterranean Sea and their return to the Atlantic Ocean (in 1956 and 1958). Tiews (1978) applied it to study fish consumption by ABFT during their stay in the North Sea (from 1951-1972). Deguara et al. (2013) proposed this method to filter out outliers and to provide more meaningful $L-W$ relationships. In the present study the latter method has been followed taking into account that most of the guidelines provided by Froese (2006) are followed.

According to Rodríguez-Roda (1964); Santos et al. (2004); Aguado and García (2005); Chapman et al. (2011), values of $K$ between 1.4 and 1.7 are values for wild ABFT in low fattening condition, far from those of spawning ABFT $(K \geq 2)$, as has been demonstrated by Rodríguez-Roda (1964); Percin and Akyol (2009; 2010); Golet and Lutcavage, unpublished data cited by Chapman et al. (2011); Deguara et al. (2012), Gordoa (2010) and Galaz (2012). Changes in mean condition factor of female bluefin tuna from the south-western North Pacific by trimester periods shown by Chen et al. (2007), also show a fall during the spawning period.

The $K$ index turns out to be a fundamental tool for determining the validity of ABFT growth models. Nevertheless, in our last studies we have established limits of between 1.4 and 2.6, which is a very broad range. Any value outside that range can be considered very unlikely from a statistical point of view. As an example, ABFT captured in the traps of the Strait of Gibraltar in the boreal spring while entering the Mediterranean Sea for spawning has a $K \geq 1.8-2$. The index for these fish will fall to $K=1.7$ at the end of the spawning season in late June.

The evolution of $K$ throughout the year confirms what has been said in the preceding paragraphs, namely that the length-weight equations adopted by SCRS (RodríguezMarín et al., 2015) underestimate the real weight of ABFT during the fattest months (September-December), while the equation for June overestimates weight. This latter fact had an immediate effect on the part of the farming sector, since the equation was applied to convert straight fork length, $(S F L)$ measured with stereocameras during the caging of ABFT, to weight at catch $(R W T)$. A review of published $L-W$ relationships and an analysis of some new data was carried out by Deguara et al. (2017) with the final objective of providing an $L-W$ equation to be used to convert to $R W T$ the ABFT $S F L$ data for fishes caught during the purse seine fishing season and transferred to cages. A new equation applicable to the Mediterranean Sea during the months of May and June was determined: $R W T=2.868410^{-5} S F L^{2.9076}$ (Deguara et al., 2017). The latter was adopted by SCRS and ICCAT in 2016, and began to be implemented in stereocameras in 2017.

The analysis of the residuals presented, in which the mean and the median values point to an important asymmetry of the residuals for both models, represents another proof of 
the underestimation of weight of the length-weight models adopted by the SCRS for eastern and western stock since 2014.

There is a large difference in the total number of growth studies carried out on ABFT and PBFT species. In the case of ABFT, the bibliography began in 1923 (Corson, 1923) and has continued in numerous and different locations: the eastern and western Atlantic, and the Mediterranean. As far as PBFT is concerned the first paper was published by Aikawa and Kato (1938), and most of them are from the western Pacific.

The review carried out in this study shows that the management of growth for the stock assessment is performed better by ISC (WCPFC) than SCRS. It is clear that over time the knowledge of growth has improved and the new models adopted must show improvements. In the Pacific, the new growth models adopted have improved the quality of the data without simply changing the previous equations. In SCRS the opposite has happened.

The coincidence of the length-weight model for the ABFT western stock (Parrack and Phares, 1979) with that of PBFT indicates that both species must have the same growth, something that is not surprising since both were the same species until 2003. Other coincidences, such as the trend of condition factor $K$ in adults and the growth in the first months of life, could ratify it. The differences between the growth curves of both species may be due to the different methodologies used and to the lack of larger specimens, mainly in the case of PBFT. In any case, it' is always easier to obtain pairs of length-weight values than to carry out a growth study using hard parts that are not always obtainable. This happened in the case of the world record of Fraser (2008) in the Atlantic and that of the giant captured in Wakayama in 2017.

The aforementioned coincidence leads us to think that the world record for PBFT (currently $517 \mathrm{~kg}$ ) will continue to increase over the years. With regard to ABFT, it appears that the official $W_{\max }$ of $725 \mathrm{~kg}$, in force since 1938, can hardly be surpassed.

The length-weight relationship model discarded by the SCRS (Parrack and Phares, 1979) fits much better (for ABFT $>160 \mathrm{~cm}$ ) than that adopted by this committee (Rodríguez-Marín et al., 2015), a model that should never provide weight values below those of PBFT.

\section{EPILOGUE}

In the assessment of ABFT resources analytical models are used that require the best possible demographic distribution of catches. It is therefore important to use very precise and suitable growth equations.

The ABFT assessment group of the SCRS remains unclear as to the growth parameters of this species. Therefore, the ICCAT Manual (ICCAT, 2010b) refers to $L_{\max }$ in the following terms: "Its maximum length can exceed $4 \mathrm{~m}$ long", and the latest reports of the SCRS (ICCAT, 2015; 2016) state: "Bluefin tuna is a long-lived species, with a lifespan of about 40 years, as indicated by radiocarbon deposition and can reach $330 \mathrm{~cm}$ (SFL) and weight up to $725 \mathrm{~kg}$." The difference between the two statements is abysmal. The result of the confusion on this matter is that in recent years the group has adopted 
absolute (growth curve) and relative growth equations (length-weight relationships) that fail to fit either of these two values while, nevertheless, ruling out models that fitted better to the biology of the growth of the species, specifically the values cited in the latest reports of the SCRS $(330 \mathrm{~cm}, S F L ; 725 \mathrm{~kg}, R W)$.

In addition to recent publications and articles submitted to the SCRS, in the present study we have shown that the absolute growth model adopted in 2016 deviates significantly, from a statistical point of view, from the permissible values of $L_{\max }$, and that the length-weight relationships adopted in 2014 significantly underestimate the weight of adult specimens.

In the Pacific Ocean, where far fewer growth studies have been made on PBFT than on ABFT in the Atlantic and Mediterranean, the management of growth models for the purposes of stock assessment in the ISC makes more sense than that carried out by the SCRS on this matter. The new models adopted by the former committee improve over the years without obfuscating the reality of the species, in stark contrast to the case of the SCRS.

The fact that models are used that underestimate ABFT size will, one way or another, affect the final results of the population analysis as well as the assessment the SCRS communicates to the Commission (ICCAT).

\section{ACKNOWLEDGEMENTS}

To Txema Galaz (Echevastar group) for facilitating the news of a giant PBFT caught in waters of Japan in March 2017; to Tamaki Shimose (AFFRC, Japan) for the information provided on this fish; to Fernando de la Gándara (IEO, Murcia) for the information provided on the growth of ABFT and PBFT in aquaculture; to Bernardo Pérez (IEO, Santander) for his help and support during the writing of this article; to Dolores Godoy (IEO, Málaga) for providing information on the Spanish fishing statistics of ABFT in the Mediterranean, and thus confirming the absence of an ABFT of 1,056 kg.

\section{BIBLIOGRAPHY}

Abid, N., S. Benchoucha, S. El Arraf, C. El Fanichi, and S.A. Baibbat. Updated length weight relationship of bluefin tuna (Thunnus thynnus) caught in Moroccan waters. Col. Vol. Sci. Pap. ICCAT, 71 (2): 1036-1040 (2015).

Aguado, F., and B. García. Changes in some morphometric relationships in Atlantic bluefin tuna (Thunnus thynnus Linnaeus, 1758) as a result of fattening process. Aquaculture, 249: 303-309 (2005).

Aikawa, H. and M. Kato. Age determination of fish. I. Nippon Suisan Gakkaishi, 7, 7988 (1938).

Akyüz, E. F. and Artüz, I. Some observations on the biology of tuna (Thunnus thynnus) caught in Turkish waters. Gen. Fish. Coun. Medit. Doc. Tech., 14: $93-99$ (1957). 
Ailloud, L. E., M.V. Lauretta, A. Hanke, W. Golet, R. Allman, M. R. Siskey, D. H. Secor, and J. M. Hoening. Improving growth estimates for Western Atlantic bluefin tuna using an integrated modeling approach. Fish. Res. 191: 17-24 (2017).

Anonymous. ISC Pacific Bluefin Tuna Atock Assessement 2016, 42 p. (2016). https://www.wcpfc.int/node/27657

Anonymous. Stock Assessment of Bluefin Tuna in the Pacific Ocean in 2014. WCPFCSC10-2014/ SA-WP-11 (2014).

https://www.wcpfc.int/node/19201

Arena, P. Observazioni sulle concentrazioni e sulla pesca del tonno e dell'alalunga nelle zone di mare meridionalli. Estratto da: Quaderni del Laboratorio di Tecnologia della Pesca. Atti X Congresso S.I.B.M. Ancona, Vol. III. N. 1 Suppl.: 77-99 (1981).

Arena, P. La pêche à la senne tournante du thon rouge (Thunnus thynnus, L.) dans les bassins maritimes occidentaux italiens. Col. Vol. Sci. Pap. ICCAT, 17 (2): 281-292 (1982).

Baglin, R. Jr. A preliminary study of the gonadal development and fecundity of the western Atlantic bluefin tuna. Col. Vol. Sci. Pap. ICCAT, 5 (2): 279-289 (1976).

Bard, F. X., J. L. Cort, and J. C. Rey. Commentaires sur la composition démographique des pêcheries de thon rouge (Thunnus thynnus) de 1'Est Atlantique et de la Méditerranée, 1960-1976. Col. Vol. Sci. Pap. ICCAT, 7: 355-365 (1978).

Bayliff, W.H. Growth and age composition of northern bluefin tuna, Thunnus thynnus, caught in the Eastern Pacific Ocean, as estimated from length-frequency data, with comments on trans-Pacific migrations. Inter-Am Trop Tuna Commission Bull, 20: 501540 (1993).

Bayliff, W. A review of the biology and fisheries for Northern bluefin tuna, Thunnus thynnus, in the Pacific Ocean; 244-295. In Interactions of Pacific tuna fisheries. Volume 2. Papers on biology and fisheries. Proceedings of the First FAO Expert Consultation on interactions of Pacific Tuna Fisheries 3-11 December 1991; Noumea, New Caledonia. Edited by: Shomura, R., J. Majkowski, and S. Langi, 439 p. (1994).

Available at: http://www.fao.org/docrep/005/T1817E/T1817E13.htm

Bayliff, W. H., Y. Ishizuka, and R. B. Deriso. Growth, movement, and attrition of northern bluefin tuna, Thunnus thynnus, in the Pacific Ocean, as determined by tagging. IATTC Bull., 20: 1-94 (1991).

Berkovich, N., A. Corriero, N. Santamaria, C. C. Mylonas, R. Vassallo-Aguis, F. de la Gándara, et al. GnRHa-mediated stimulation of the reproductive endocrine axis in captive Atlantic bluefin tuna, Thunnus thynnus. Gen. Comp. Endocrinol. 175, 55-64 (2013).

Block, B., G. Lawson, A. M. Boustany, M. W. Stokesbury, M. Castleton, A. Spares, J. D. Neilson, and S. E. Campana. Preliminary results from electronic tagging of bluefin 
tuna (Thunnus thynnus) in the Gulf of St. Lawrence, Canada. Col. Vol. Sci. Pap. ICCAT, 64 (2): 469-479 (2009).

Bigelow, H. B., W. C. Schroeder. Fishes in the Gulf of Maine. Fish Bull Wild Ser 53: 1577 (1953).

Busawon, D. S., E. Rodríguez-Marín, P. L. Luque, R. Allman, B. Gahagan, W. Golet, E. Koob, M. Siskey, M. Ruiz, P. Quelle. 2015. Evaluation of an Atlantic bluefin tuna otolith reference collection. Col. Vol. Sci. Pap. ICCAT, 71: 960-982 (2015).

Butler, M., J. Caddy, C. A. Dickson, J. Hunt, and C. Burnett. Apparent age and growth, based on otolith analysis, of giant bluefin tuna (Thunnus thynnus) in the 1975-1976 Canadian catch. Col. Vol. Sci. Pap, ICCAT, 6 (2): 31/8-330 (1977).

Caddy, J., C. A, Dickson, and J. A. Butler. Age and growth of giant bluefin tuna (Thunnus thynnus thynnus) taken in Canadian waters in 1975. Fisheries Research Canada. Manuscript Report Series, 1395: 17p. (1976).

Chapman, E. W., C. Jørgensen, and M. E. Lutcavage. Atlantic bluefin tuna (Thunnus thynnus): A state-dependent energy allocation model for growth, maturation, and reproductive investment. Can. J. Fish. Aquat. Sci., 68: 1934-1951 (2011).

Chen, K., P. Crone, and C. Hsu. Reproductive biology of female Pacific bluefin tuna Thunnus orientalis from south-western North Pacific ocan. Fisheries Science, 72: 985994 (2006).

Corriero, A., S. Kakakulak, N. Santamaría, M. Deflorio, D. Spedicato, P. Addis, A. Fenech-Farrugia, R. Vassallo-Agius, J. M. de la Serna, I Oray, A. Cau, and G. De Metrio. Size and age at sexual maturity of femelle bluefin tuna (Thunnus thynnus L. 1758) from the Mediterranean Sea. J. Appl. Ichthyol., 21: 483-486 (2005).

Corrigan, S., J. Neilson, and P. Stacey. 2006 summary of ongoing Canadian bluefin tuna sampling activities supported by the ICCAT bluefin tuna year program. Col. Vol. Sci. Pap. ICCAT, 60 (4): 1345-1348 (2007).

Corson, R.H. The "weight for age curve" of tuna. Fishing Gazette, London 87: 519-520 (1923).

Cort, J. L. Biología y pesca del atún rojo, Thunnus thynnus (L.), del mar Cantábrico. Publicaciones Especiales Inst. Esp. Oceanog., Num. 4: 272 p. (1990).

Cort, J. L. Age and growth of the bluefin tuna, Thunnus thynnus (L.) of the Northeast Atlantic. Col. Vol. Sci. Pap. ICCAT, 35: 213-230 (1991).

Cort, J. L. Growth and the equation applied to the eastern bluefin tuna (Thunnus thynnus) stock of the north Atlantic, twenty years on. ICCAT, SCRS/2009/124, 29 p. (2009). Available from:

http://iccat.int/Documents/CVSP/CV065 2010/no 3/CV065031103b.pdf 
Cort, J. L., I. Arregui, V. Estruch, and S. Deguara. Validation of the growth equation applicable to the eastern Atlantic bluefin tuna, Thunnus thynnus (L.), using $L_{\max }$, tagrecapture and first dorsal spine analysis. Reviews in Fisheries Science \& Aquaculture, 22: 3, 239-255 (2014).

Cort, J. L., S. Deguara, T. Galaz, B. Mèlich, I. Artetxe, I. Arregi, J. Neilson, I. Andrushchenko, A. Hanke, M. N. Dos Santos, V. Estruch, M. Lutcavage, J. Knapp, G. Compeán-Jiménez, R. Solana-Sansores, A. Belmonte, D. Martínez, C. Piccinetti, A. Kimoto, P. Addis, M. Velasco, J. M. De la Serna, D. Godoy, T. Ceyhan, I. Oray, S. Karakulak, L. Nøttestad, A. López, O. Ribalta, N. Abid, and M. Idrissi. Determination of $L_{\max }$ for Atlantic Bluefin Tuna, Thunnus thynnus (L.), from Meta-Analysis of Published and Available Biometric Data, Reviews in Fisheries Science, 21: 2, 181-212 (2013).

Cort, J. L., V. D. Estruch, M. N. Santos, A. Di Natale, N. Abid, J. M. de la Serna. On the variability of the length-weight relationship for Atlantic bluefin tuna, Thunnus thynnus (L.). Reviews in Fisheries Science \& Aquaculture 23:1, 23-38 (2015).

Cort, J. L., V. D. Estruch. Analysis of the length-weight relationships for the western Atlantic Bluefin tuna, Thunnus thynnus (L.). Reviews in Fisheries Science \& Aquaculture 24: 2, 126-136 (2016).

Cort, J. L. and V. D. Estruch. Analysis of the length-weight relationships for the Atlantic bluefin tuna, Thunnus thynnus (L.). Col. Vol. Sci. Pap. ICCAT, 73 (6): 22222254 (2017).

Cort, J. L., V. D. Estruch, and S. Deguara. Validation of the grow equations applicable to the Atlantic bluefin tuna, Thunnus thynnus (L.), using $L_{\max }$, tag-recapture, lengthweight relationships, condition factor and first dorsal spine analysis. ICCAT, SCRS/2017/022; 21 p. (2017).

Crane, J. Notes on the biology and ecology of giant tunas, Thunnus thynnus Linnaeus, observed at Portland, Maine. Zoologica 21 (16): 207-212 (1936).

Deguara, S., M. Gatt, S. Caruana, and C. Agius. Changes in length-weight relationships of Atlantic bluefin tuna, Thunnus thynnus, caught by Maltese longliners during the years 2008-2011. Col. Vol. Sci. Pap. ICCAT. 68: 223- 229 (2012).

Deguara, S. J. L. Cort, T. Galaz,V. D. Estruch, and E. J. Belda Perez. Use of Fulton's condition factor to filter out outliers from Atlantic bluefin tuna (Thunnus thynnus, L.) length-weight relationships. Col. Vol. Sci. Pap. ICCAT, 69 (2): 671-683 (2013).

Deguara, S., A. Gordoa, J. L. Cort, R. Zarrad, N. Abid, P. G. Lino, S. Karakulak, I. Katavic, L. Grubisic, M. Gatt, M. Ortiz, C. Palma, J. J. Navarro Cid, and F.Lombardo. Determination of length-weight equation applicable to Atlantic bluefin tuna (Thunnus thynnus) during the purse seine fishing season in the Mediterranean Sea. Col. Vol. Sci. Pap. ICCAT, 73 (7): 2324-2332 (2017). 
De la Serna, J. M., D. Macias, J. M. Ortiz de Urbina, E. Alot, and P. Rioja. Análisis de la pesquería española del pez espada (Xiphias gladius) en el Mediterráneo. Col. Vol. Sci. Pap. ICCAT, 56 (3): 864-871 (2004).

Di Natale, A., A. Mangano, A. Asaro, B. Bascone A. Celona, A. Navarra, M. Valastro, and B. Zava. Size frequency composition of bluefin tuna catches in the Tyrrhenian sea and in the Straits of Sicily in the period 1998-2001. Col. Vol. Sci. Pap. ICCAT, 52 (1): 171-198 (2003).

Di Natale, A., P. Addis, A. Cau, A. Celona, N. Cingolani, M. Deflorio, G. De Metrio, C. Fuggetti, F. Garibaldi, A. Mangano, G. Marano, G. Palandri, A. M Pastorelli, C. Piccinetti, L. Relini Orsi, and M. Valastro. Pilot study report on tuna sport fishing activity in Italy. Col. Vol. Sci. Pap. ICCAT, 58 (4): 1360-1371 (2005).

Di Natale, A., S. Bonhommeau, P. de Bruyn, D. Die, G. D. Melvin, R. Mielgo Bregazzi, A. Pagá García, C. Palma, C. Porch, Y. Takeuchi, and S. Tensek. Bluefin tuna weight frequencies from selected market and auction data recovered by GBYP. Col. Vol. Sci. Pap. ICCAT, 73 (6): 2129-2149 (2017).

Farber, M. I., and T. W. Chewning. An update of U.S. bluefin tuna tagging. Col. Vol. Sci. Pap. ICCAT, 9 (2): 463-469 (1980).

Farber, M. I., and D. W. Lee. Ageing western Atlantic bluefin tuna, Thunnus thynnus, using tagging data, caudal vertebrae and otoliths. Col. Vol. Sci. Pap. ICCAT, 15: 288301 (1981).

Foreman, T. Estimates of age and growth, and an assessment of ageing techniques, for northern bluefin tuna, Thunnus thynnus, in the Pacific Ocean. IATTC Bull., 21, 75-123 (1996).

Fraser, K. Possessed. World Record Holder for Bluefin Tuna. Kingstown, Nova Scotia: T \& S Office Essentials and printing, 243 p. (2008).

Froese, R. Cube law, condition factor and weight-length relationships: history, metaanalysis and recommendations. J. Appl. Ichthyol. 22: 241-253 (2006).

Fromentin, J. M., J. E. Powers. Atlantic bluefin tuna: population dynamics, ecology, fisheries and management. Fish Fish 6: 281-306 (2005).

Galaz, T. Eleven years -1995-2005- of experience on growth of bluefin tuna (Thunnus thynnus) in farms. Col. Vol. Sci. Pap. ICCAT. 68 (1): 163- 175 (2012).

García A., F. Alemany, P. Vélez-Belchy, J. M. Rodríguez, J. L. López Jurado, C. González Pola, and J. M. De la Serna. Bluefin and frigate tuna spawning off Balearic archipelago in the environmental conditions observed during the 2002 spawning season. Col. Vol. Sci. Pap. ICCAT, 55: 1261-1270 (2003).

García, A., F. Alemany, J. M. de la Serna, I. Oray, S. Karakulak, L. Rollandi, A. Arigo, and S. Mazzola. Preliminary results of the 2004 bluefin tuna larval surveys off different Mediterranean sites (Balearic Archipelago, Levantine Sea, and the Sicilian Channel). Col. Vol. Sci. Pap. ICCAT, 58: 1420-1428 (2005). 
Golet, W. J. Somatic condition, growth and distribution of Atlantic bluefin tuna (Thunnus thynnus) in the Gulf of Maine. Submitted to the University of New Hampshire in Partial Fulfillment of the Requirements for the Degree of Doctorate of Phylosophy in Zoologie. May, 2010, 319 p. (2010).

Gordoa, A. Estimating the fattening factor of Atlantic bluefin tuna (Thunnus thynnus) on tuna farms: the Ametlla de Mar facility as a case study. Col. Vol. Sci. Pap. ICCAT, 65 (3): 848-857 (2010).

Grubbs, F. E. Procedures for detecting outlying observations in samples. Technometrics 11: 1-21 (1969).

Hamre, J., C. Maurin, J. Rodríguez-Roda, and K. Tiews. Report of the Bluefin Tuna Working Group. Observations on the size composition of Bluefin tuna catches from 1967-1969. ICES Cooperative Research Report, Ser. A., 23: 49 p. (1971).

Hattour, A. Analyse de l'âge, de la croissance et des captures des thons rouges (Thunnus thynnus) et des thonines (Euthynnus alleteratus L.) pêchés dans les eaux tunisiennes. Bull. Inst. Natl. Sci.Tech. Océanogr. Pêche Salammbô, 11: 5-39 (1984).

Heldt, H. Le thon rouge et sa pêche. 10 Rapp. Comm. Internat. Explor. Medit., vol. 11: 311-358 (1938).

Hirota, H., M. Monta, and N. Taniguchi. An instance of the maturation of 3 full years old bluefin tuna cultured in the floating net. BulLlap.Soc.Sci.Fish., 42 (8): 939 (1976).

Hoaglin, D.C., Mosteller, F. and Tukey, J.W. (editors). Understanding Robust and Exploratory Data Analysis, John Wiley \& Sons, New York (1983).

Hurley, P. C. F. and T. D. Iles. An unusual bluefin tuna tag return. Col. Vol. Sci. Pap. ICCAT, 17 (2): 295-298 (1982).

ICCAT. Data record, vol. 7, 359 p. (1976).

ICCAT. Estimates of unreported Atlantic bluefin tuna catches. Col. Vol. Sci. Pap. ICCAT 46: 159-160 (1997).

http://iccat.int/Documents/CVSP/CV046 1997/no 2/CV046020159.pdf

ICCAT. Length-weight relationships adopted by the SCRS for major species. http://www.iccat.int/Documents/SCRS/Manual/Appendices/Appendix\%204\%20III\%20 Length-weight.pdf (2006).

ICCAT. Report of the 2010 Atlantc bluefin tuna stock assessment session. (Madrid, Spain - September 6 to 12, 2010a). http://www.iccat.int/Documents/Meetings/Docs/2010_BFT_ASSESS_REP_ENG.pdf (2010a). 
ICCAT. ICCAT Manual. Description of species. Chapter 2; 2.1.5 Atlantic Bluefin Tuna, 93-111 (2010b).

http://iccat.int/Documents/SCRS/Manual/CH2/2 15 BFT ENG.pdf

ICCAT. Report of the Standing Committee on Research and Statistics (SCRS), 348 p. http://www.iccat.int/Documents/Meetings/Docs/2014-SCRS-REP_ENG.pdf (2014a).

ICCAT. Report of the 2014 Atlantic Bluefin Tuna Stock Assessment session. Madrid, Spain-September 22 to 27, 2014; 178 p.

http://iccat.int/Documents/Meetings/Docs/2014 BFT ASSESS-ENG.pdf (2014b).

ICCAT. Report of Standing committee on research and statistics (SCRS). Madrid, Spain, 28 September to 2 October 2015, 348 p. (2015).

https://www.iccat.int/Documents/Meetings/SCRS2015/SCRS_PROV_ENG.pdf

ICCAT. Report of Standing committee on research and statistics (SCRS). Madrid,

Spain, 3 to 7 October 2016, 425 p. (2016)

http://iccat.int/Documents/Meetings/Docs/2016_SCRS_ENG.pdf

Itoh, T. Contributions of different spawning seasons to the stock of Pacific bluefin tuna Thunnus orientalis estimated from otolith daily increments and catch-at-length data of age-0 fish. Nippon Suisan Gakkaishi, 75: 412-418 (2009).

Juan-Jordá, M. J., I. Mosqueira, J. Freire, and N. K. Dulvy. Life in 3-D: life history strategies in tunas, mackerels and bonitos. Rev. Fish. Biol. Fisheries. DOI 10.1007/s11160-012-9284-4, 21 p. (2012).

Kai, M. Weight-length relationship of North Western PBF. Working paper submitted to the ISC PBF Working Group Meeting, 11-18 December 2007, Shimizu, Japan. ISC/07/PBFWG-3/07 (2007).

Karakulak, S, I. Oray, A. Corriero, M. Deflorio, N. Santamaria, S. Desantis, and G. De Metrio. Evidence of a spawning area for the bluefin tuna (Thunnus thynnus) in the Eastern Mediterranean. J. Appl. Ichthyol., 20: 318-320. (2004).

Knapp, J., G. Heinisch, and M. Lutcavage. Preliminary results on the reproductive status of Atlantic bluefin tuna sampled in the Gulf of Mexico during spawning season, 2007-2008. Col. Vol. Sci. Pap. ICCAT, 65 (3): 822-827 (2010).

Landa, J., E. Rodríguez-Marín, P. Luque, M. Ruíz, and P. Quelle. Growth of bluefin tuna (Thunnus thynnus) in the North-eastern Atlantic and Mediterranean based on backcalculation of dorsal spine annuli. ICCAT, SCRS/2011/178, 12 p. (2011).

Landa, J., E. Rodríguez-Marín, P. Luque, M. Ruíz, and P. Quelle. Growth of bluefin tuna (Thunnus thynnus) in the North-eastern Atlantic and Mediterranean based on backcalculation of dorsal spine annuli. Fisheries Research, 170: 190-198 (2015).

Lebedeff, W. Paradise for big Game Fishing. Tunny, 700 kgs.; Swordfish, 180 kgs.; Shark, 1,800 kgs. Winter season 1935-36 in Turkey. The Fishing Gazette, London 113 (3102); October 3, 1936: 420-421 (1936). 
La Mesa, M. Sinopoli, and F. Andaloro. Age and growth of juvenile bluefin tuna Thunnus thynnus from the Mediterranean Sea (Sicily, Italy). Sci. Mar., 69 (2): 241-249 (2005).

Le Gall, J. Contribution à l'étude de la biologie du thon rouge (Thunnus thynnus L.). ICES, J. Cons., 2 (3): 309-331 (1927).

Luque, P., E. Rodríguez-Marín, M. Ruíz, P. Quelle, J. Landa, and D. Macías. A review of direct ageing methodology using dorsal fin spine from Atlantic bluefin tuna (Thunnus thynnus). ICCAT, SCRS/2011/176, 22 p. (2011).

Luque, P., E. Rodríguez-Marín, M. Ruíz, P. Quelle, J. Landa, D. Macías, and J. M. Ortiz de Urbina. Direct ageing of Thunnus thynnus from east Atlantic and western Mediterranean using dorsal fin spines. J. Fish Biol., 84: 1876-1903 (2014).

Mather, F. J. III, Mason Jr, J. M. and Jones, A. C. Historical document: life history and fisheries of Atlantic bluefin tuna. NOAA Technical Memorandum, NMFS-SEFSC-370, Miami Fl, 165 p. (1995).

Murua, H., E. Rodríguez-Marín, J. D. Neilson, J. H. Farley, and M. J. Juán-Jordá. Fast versus slow growing tuna species: age, growth, and implications for population dynamics and fisheries management. Rev Fish Biol Fisheries. DOI 10.1007/s11160017-9474-1 (2017).

Neghli, N., and A. Nouar. Estimation de 1'âge des spécimens de thon rouge (Thunnus thynnus) pêches sur les côtes algérienes. Col. Vol. Sci. Pap. ICCAT, 70 (1): 232-240 (2014).

Neilson, J., and S. E. Campana. A validated description of age and growth of western Atlantic bluefin tuna (Thunnus thynnus). Can. J. Fish. Aquat. Sci., 65: 1523-1527 (2008).

Okiyama, M. Occurrence of the postlarvae of bluefin tuna, Thunnus thynnus, in the Japan Sea. Bull. Japan Sea Reg. Fish. Res. Lab., 25: 89-97 (1974).

Okiyama, M. Successful spawning of some holoepipelagic fishes in the Sea of Japan and zoogeographical implications. In Japan-Soviet Joint Symp. Aquaculture, 7: 223-33 (1979).

Parrack, M., and P. Phares. Aspects of the growth of Atlantic bluefin tuna determined from marck-recapture data. Col. Vol. Sci. Pap. ICCAT, 8: 356-366 (1979).

Percin, F., and O. Akyol. Length-weight and length-length relationships of bluefin tuna, Thunnus thynnus, in the Turkish part of the eastern Mediterranean sea. J. Appl. Ichthyol., 25: 782-784 (2009).

Percin, F., and O. Akyol. Some morphometric relationships in fattened bluefin tuna, Thunnus thynnus from Turkish Aegean Sea. J. Animal Vet. Adv., 9: 1684-1688 (2010). 
Restrepo, V. R., G. A. Díaz, J. F. Walter, J. Neilson, S. E. Campana, D. Secor, and R. L. Wingate. Updated estimate of the growth curve of western Atlantic bluefin tuna. Aquat. Living Resour., 23: 335-342 (2010).

Rey, J. C., E. Alot, and J. L. Cort. Análisis de las capturas de atún rojo (Thunnus thynnus) por las almadrabas españolas en 1984-1985. Col. Vol. Sci. Pap. ICCAT, 26: 300-307 (1987).

Richards, F. J. A flexible growth function for empirical use. J. Exp. Bot., 10: 290-301 (1959).

Richardson, D. E., K. E. Marancik, J. R. Guyyon, M. E. Lutcavage, B. Galuardi, C. H. Lam, H. J. Walsh, S. Wildes, D. A. Yates, and J. A. Hare. Discovery of spawning ground reveals diverse migration strategies in Atlantic bluefin tuna (Thunnus thynnus). PNAS, vol. 113; n. 12: 3299-3304 (2016).

Ricker, W. E. Computation and interpretation of biological statistics of fish populations. Bulletin of the Fisheries Board of Canada 191: 1-382 (1975).

Rivas, L. R. A preliminary report on the spawning of the western North Atlantic bluefin tuna (Thunnus thynnus) in the Straits of Florida. Bull. Mar. Sci. Gulf. Caribb., 4 (4): 302-322 (1954).

Rodríguez-Marín, E., P. L. Luque, P. Quelle, M. Ruíz, and B. Pérez. Age determination analysis of Atlantic Bluefin Tuna (Thunnus thynnus) within the biological and genetic sampling and analysis contract (GBYP). Col. Vol. Sci. Pap. ICCAT, 70 (2): 321-331 (2013).

Rodríguez-Marín, E., and M. Ortiz. Further analysis results of biometric relationships of Atlantic bluefin tuna, attending to the recommendation of ICCAT bluefin tuna Group (2014 ICCAT Bluefin Data Preparatory Meeting). SCRS/2014/053 Rev, 17 p. (2014a).

Rodríguez-Marín, E., J. M. Ortiz de Urbina, N. Abid, E. Alot, I. Andrushchenko, S. Deguara, A. Di Natale, M. Gatt, W. Golet, S. Karakulak, A. Kimoto, D. Macias, P. Quelle, S. Saber, M. N. Santos, J. Walter and R. Zarrad. Length weight relationships for Atlantic bluefin tuna (Thunnus thynnus). ICCAT, SCRS/2014/053, 19 p. (2014b).

Rodríguez-Marín, E., M. Ortiz, J. M. Ortiz de Urbina, P. Quelle, J. Walter, N. Abid et al. Atlantic Bluefin Tuna (Thunnus thynnus) Biometrics and Condition. Plos ONE 10 (10): e0141478.doi: 10.1371/journal.pone.0141478 (2015).

Rodríguez-Marín, E., P. Quelle, M. Ruíz, D. Busawon, W. Golet, A. Dalton, and A. Hanke. Updated comparison of age estimates from paired calcified structures from Atlantic bluefin tuna. ICCAT SCRS/2016/134, 6 p. (2016).

Rodríguez-Marín, E., P. Quelle, M. Ruíz, E. Ceballos, and L. E. Ailloud. Direct ageing for constructing age-length keys and reestimating the growth curve for East Atlantic and Mediterranean bluefin tuna. ICCAT/2017/170, 9 p. (2017). 
Rodríguez-Roda, J. Biología del atún, Thunnus thynnus (L.), de la costa sudatlántica española. Inv. Pesq., 25: 33-146 (1964).

Rodríguez-Roda, J. Fecundidad de atún, Thunnus thynnus (L.), de la costa sudatlántica española. Inv. Pesq., 31 (1): 33-52 (1967).

Rooker, J., J. Alvarado, B. Block, H. Dewar, G. De Metrio, E. Prince, E. RodríguezMarín, and D. Secor. Life and Stock Structure of Atlantic Bluefin Tuna (Thunnus thynnus). Reviews in Fisheries Science, 15: 265-310 (2007).

Ross, M. The glory days of the giant Scarborough tunny. British Library Cataloguing in Publication Data. ISBN: 978-0-9566375-0-5, 390 p. (2010)

Russell, F.S. Tunny investigations made in the North Sea on Col. E.T. Peel's Yacht "St. George", summer 1933. Part I. Biometric data. Journal of the Marine Biologic Association of the United Kingdom, London 19 (2): 503-522 (1934).

Santos Guerra, Al. Las pesquerías de túnidos en Canarias durante 1974. Col. Vol. Sci. Pap. ICCAT, 5 (1): 5-10 (1976a).

Santos Guerra, Al. La pesca del atún rojo (Thunnus thynnus) en Canarias. Resultados preliminares (enero-octubre, 1975). Col. Vol. Sci. Pap. ICCAT, 5 (2): 242-243 (1976b).

Santos Guerra, Al. Descripción de la pesquería del atún rojo (Thunnus thynnus) en Canarias. Col. Vol. Sci. Pap. ICCAT, 11: 396-398 (1980).

Santos, M. N., A. García, P. Gil Lino, and M. Hirofumi. Length-weight relationships and weight conversion factors for bluefin tuna (Thunnus thynnus) from Algarve: Prior to and after fattening. Col. Doc. Sci. Pap. ICCAT, 56: 1089-1095 (2004).

Sarà, R. La pesca del tonno in Tirreno nel 1969. Bolletino di Pesca, Piscicultura e Idrobiología, vol. XXIV, fas 2: 159-164 (1969).

Sawada, Y., M. Seoka, K. Kato, T. Tamura, M. Nakatani, S. Hayashi, T. Okada, K. Tose, S. Miyashita, O. Murata, and H. Kumai. Testes maturation of reared Pacific bluefin tuna Thunnus orientalis at two-plus years old. Fisheries Science, 73: 1070-1077 (2007).

Secor, D. H., Busawon, D.S., Gahagan, B., Golet, W., Koob, E., Neilson, J.D., Siskey, M. Conversion factors for Atlantic bluefin tuna fork length from measures of snout length and otolith mass. Col. Vol. Sci. Pap. ICCAT, 70: 364-367 (2014).

Shiao, J. C., H. B. Lu, J. Hsu, H. Y. Wang, S. K. Chang, M. Y. Huang, and T. Ishihara. Changes in size, age, and sex ratio composition of Pacific bluefin tuna (Thunnus orientalis) on the northwestern Pacific Ocean spawning grounds. ICES Journal of Marine Science, 74: 204-214 (2017).

Shimose, T., and T. Ishihara, 2015. A manual for age determination of Pacific bluefin tuna Thunnus orientalis. Bull. Fish. Res. Agen. No. 40: 1-11 (2015).

https://www.fra.affrc.go.jp/bulletin/bull/bull40/40-01.pdf 
Shimose, T., T. Tanabe, K. Chen, and C. Hsu. Age determination and growth of Pacific bluefin tuna, Thunnus orientalis, off Japan and Taiwan. Fisheries Research 100: 134139 (2009).

Smith, S., J. Neilson, and P. Stacey. Summary of ongoing Canadian bluefin tuna sampling activities reported by the ICCAT bluefin tuna year program. Col. Vol. Sci. Pap. ICCAT, 59 (3): 824-828 (2006).

Sawada, Y. M. Seoka, K. Kato, T. Tamura, M. Nakatani, S. Hayashi, T. Okada, K. Tose, S. Miyashita, O. Murata, and H. Kumai. Testes maturation of reared Pacific bluefin tuna Thunnus orientalis at two-plus years old. Fisheries Science 73: 1070-1077 (2007).

Tanabe, T. and M. Kai. Estimates of the age-length relationship of Pacific bluefin tuna with descriptive analysis on uncertainties remained. ISC/07/PBFWG-2/03 (2007).

Tanaka, Y., M. Mohri, and H. Yamada. Distribution, growth and hatch date of juvenile Pacific bluefin tuna Thunnus orientalis in the coastal area of the Sea of Japan. Fish. Sci., 73: 534-542 (2007).

Tiews, K. Synopsis of biological data on bluefin tuna, Thunnus thynnus (Atlantic and Mediterranean). FAO, Fish. Rep. (6) 2: 422-481 (1963).

Tiews, K. On the disappearance of bluefin tuna in the North Sea and its ecological implications for herring and mackerel. Rapp. P-v. Reun. Cons. Cons. Int. Expl. Mer, 172: 301-309 (1978).

Tukey, J. W. Exploratory data analysis. Reading, MA: Addison-Wesley Publishing Co.: 44 (1977).

Turner, S. C., and V. R. Restrepo. A review of the growth rate of West Atlantic bluefin tuna, Thunnus thynnus, estimated from marked and recaptured fish. Col. Vol. Sci. Pap. ICCAT, 42: 170-172 (1994).

von Bertalanffy, L. A quantitative theory of organic growth (inquiries on growth laws. II). Human. Biol., 10: 181-213 (1938).

Yamanaka and staff of the Nankai Regional Fisheries Research laboratory Kochi, Japan. Synopsis of biological data on kuromaguro, Thunnus orientalis (Temminck and Schlegel) 1842 (Pacific Ocean). Species Synopsis No. 6. FAO Fisheries Biology Synopsis No. 49 (1963).

Yamasaki, I., W. Doi, K. Oshima., and T. Tanabe. Research activities for biology on reproduction, ageing, growth and recruitment monitoring of Pacific bluefin tuna. International Scientific Committee for Tuna and Tuna-like species in the North Pacific Ocean. ISC/10-1/PBFWG/10, 7 p. (2010).

Yukinawa, M. and Y. Yabuta. Age and growth of the bluefin tuna, Thunnus thynnus (Linnaeus), in the North Pacific Ocean. Rep. Nankai Reg. Fish. Res. Lab., 25: 1-18 (1967). 